\title{
REVIEW PAPER ON BEVERAGE AGRO- INDUSTRIAL WASTEWATER TREATMENT PLANT BIO-SLUDGE FOR FERTILIZER POTENTIAL IN ETHIOPA
}

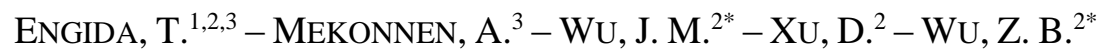 \\ ${ }^{I}$ School of Resources and Environmental Engineering, Wuhan University of Technology, \\ Wuhan, P.R. China \\ (e-mail: zewedenahomruhama@gmail.com) \\ ${ }^{2}$ State Key Laboratory of Freshwater Ecology and Biotechnology, Institute of Hydrobiology, \\ Chinese Academy of Sciences, Wuhan, P.R. China \\ ${ }^{3}$ Department of Industrial Chemistry, Addis Ababa Science and Technology University, Addis \\ Ababa, Ethiopia \\ *Corresponding authors \\ e-mail:wuzb@ihb.ac.cn (Wu, Z.B.);wujunmei@ihb.ac.cn (Wu, J.M.) \\ phone: +86-027-6878-0020; fax: +86-027-6878-0675 \\ (Received 27 $7^{\text {th }}$ Mar 2019; accepted $19^{\text {th }}$ Jun 2019)
}

\begin{abstract}
Agro-industrial sectors in Ethiopia are highly expanding sector and offers substantial challenges for the environment and public health. The brewery industries use large quantities of water for their production processes and at the end, they discharged large amount of effluents that contains a high strength organic waste. The main objective of this review paper is to discuss and summarize the characteristics, treatment techniques, fertilizer potential and other available management options of breweries sludge generated from wastewater treatment plants. Recent (2015) research finding indicated that the brewery sludge contains a very high nitrogen and potassium content, i.e., $420.25 \mathrm{~kg} \mathrm{ha}^{-1}$ and $840 \mathrm{~kg} \mathrm{ha}^{-1}$ respectively compared to the control. Scientific evidences indicated that brewery sludge amended soil they have the tendency to produce more yields $\left(4081.6 \mathrm{~kg} \mathrm{ha}^{-1}\right)$. Brewery sludge has also other beneficial advantages in production of biogas and building materials with co-digestion with other organic solid residues. The probable drawbacks of the use of sludge on agricultural land application is its pollutant loads including heavy metals, organic compounds and pathogens. Therefore, more research investigation has to be done on the possible sludge treatment mechanisms and the feasibility of sludge generated from brewery industries for agricultural recycling.
\end{abstract}

Keywords: brewery sludge, nutrient, treatment plant, fertilizer and yield

\section{Introduction}

\section{Background information and justification}

Rapid industrialization and urbanization in Ethiopia demanded huge increase in the extraction of resources and release of huge volume of wastes. Agro-industrial sectors in Ethiopia are a highly expanding sector and offers substantial challenges for the environment and public health (Tadese and Seyoum, 2015). Even if, the brewing sectors hold a planned economic position by increasing their production capacity (Fillaudeau et al., 2006). But, they also become one of the known industry by producing by-products such as effluent, spent grain, excess yeast and sludge from the wastewater treatment plant (Alemu et al., 2017). The brewery industry uses large quantities of water and lastly discharged large amount of effluents that contains a high strength organic wastes (Kanagachandran and Jayaratne, 2006). 
Besides its advantage, at moderate and low temperatures, removal of Chemical oxygen demand (COD) by Up-flow Anaerobic Sludge Blanket (UASB) reactor is limited and long hydraulic retention time is needed to provide efficient hydrolysis. Therefore, anaerobic effluent requires post- treatment to remove the remaining Chemical oxygen demand (COD), nutrients and pathogens. Post- treatment of Up-flow Anaerobic Sludge Blanket (UASB) reactor effluent by aeration systems is one among the different techniques (Bodík, 2005). An aerobic treatment process oxidized organic substances to carbon dioxide, water, sulfate, phosphate and nitrate by different microbial communities dominated by heterotrophic bacteria and fungi. This aerobic process produces large volumes of sludge requiring further treatment and disposal (Stocks et al., 2002). According to Stocks et al. (2002) report, the UK breweries generates around $40-50 \mathrm{~m}^{3}$ of brewery sludge has been removed by tanker each weekday for application to local agricultural land. The 1991 reports also indicate that the beer Thai generates 100-120 $\mathrm{m}^{3}$ /day of sludge as a waste (Babel et al., 2009).

There are different disposal methods of sludge such as landfilling, solidification, incineration, deep well injection and land application (Dolgen et al., 2004). Landfill is the common disposal method of brewery wastewater treatment plant sludge. Whereas, land application is an alternative option to avoid these high cost techniques, landfill cost and available of land space as well as public opposition on the offensive odor problems. Most research investigation shows that land application of agro-industrial wastewater treatment plant sludge for agricultural purposes can be recommended as an ultimate disposal alternative without any hazardous effect, since the presence of low heavy metal concentration and high organic carbon content are typical features of agro-industry sludge for soil conditioner. However, if it is not properly managed, potential risks to both environment and public health may occur from the accumulation of heavy metals (lead, cadmium, zinc and mercury), organic compounds, salts and pathogen contamination in soil and crops resulting such components entering in to the food chain (Dolgen et al., 2004; Babel et al., 2009; Olowu et al., 2012).

The application of sludge generated by industrial plants is limited due to fears of the accumulation of toxic matters in soils and plants. There are little scientific evidences in Ethiopia on the application of brewery wastewater sludge for increment of productivity of different crops through supplying nutrients and organic matter. Alemu et al. (2017) conducted a field trial in Daker, Harari regional state of eastern Ethiopia using different ratios of brewery sludge and commercial fertilizer to grow sorghum. Results demonstrated that $15 \mathrm{t} \mathrm{ha}^{-1}$ of brewery wastewater sludge amended sorghum plots produce crop yields higher than that of commercial fertilizer. In line to this, Wendimagegn (2016) has also investigated similar results, i.e., addition of $2.5 \%$ BWS produced more number of tomato fruits (16.33) compared with addition of $200 \mathrm{mg}$ of urea/kg of soil and control yields 13.0 and 7.67 tomato fruits respectively. However, these studies are not adequate enough to conclude on the feasibility of sludges generated from brewery industries for agricultural recycling. Brewery sludge is the easiest byproduct to handle but the most difficult due to its diverse in characteristics and variable composition that vary with the raw materials and product manufacturing process systems followed. Due to the increasing environmental issues and strict regulations, there should be further investigation on the feasibility, levels of application, economic benefits and assessing the environmental safety of brewery industrial wastewater treatment plant sludges to utilize it in an environmentally friendly approach (Erdem and Ok, 2002; Thomas and Rahman, 2006; Abushammala et al., 2009). 


\section{Review of literature}

By amount, beer is the fifth highest consumed beverage in the world next to tea, carbonated drinks, milk, and coffee (Fillaudeau et al., 2006). The brewing steps for beer produce large volume of wastewater effluent and solid wastes that must be discarded of without affecting in negative way the quality of water and soil. According to dos Santos Mathias et al. (2014), some of the solid waste that can come from the breweries are waste yeast, hot rub as well as the spent diatomite. This kind of wastes creates a residual sediment layer at the fermenter bottom. Every year in Ethiopia about 4 million hL of beer is usually produced. Since all Ethiopian breweries used diat-omite forclarification used in the total amount of BWS produced each year is estimated to be about 69,000 metric tons (dos Santos Mathias et al., 2014).

\section{Beverage and its wastewater treatment systems}

\section{Beer production process}

Beer is a fermented beverage which has low alcohol content and made from barley, wheat, maize and other grains. The beer production steps include grinding of the malt to grist, mixing of grist with water to produce mash in the mash tun, wort production, separation of grist residues from liquid wort, boiling of wort with hops, separation of the wort from the trub/hot break, addition of yeast to cooled wort, fermentation, separation of spent yeast by filtration, centrifugation or settling and bottling or kegging (Ramya et al., 2015). In line to this production, wastewater management and waste disposal becomes a major cost factor and an important factor in the running of a brewery operation. Every brewery tries to keep waste disposal costs low whereas the legislation imposed for waste disposal by authorities becomes more stringent. Water consumption in a brewery is an economic parameter and a tool to determine its process performance in comparison with other breweries. Furthermore, the position of beer as a natural product leads the brewers to pay attention to their marketing image and to make waste treatment (wastewater, spent grain, Kieslguhr sludge, yeast surplus) into account as shown in Figure 1 (Fillaudeau et al., 2006)

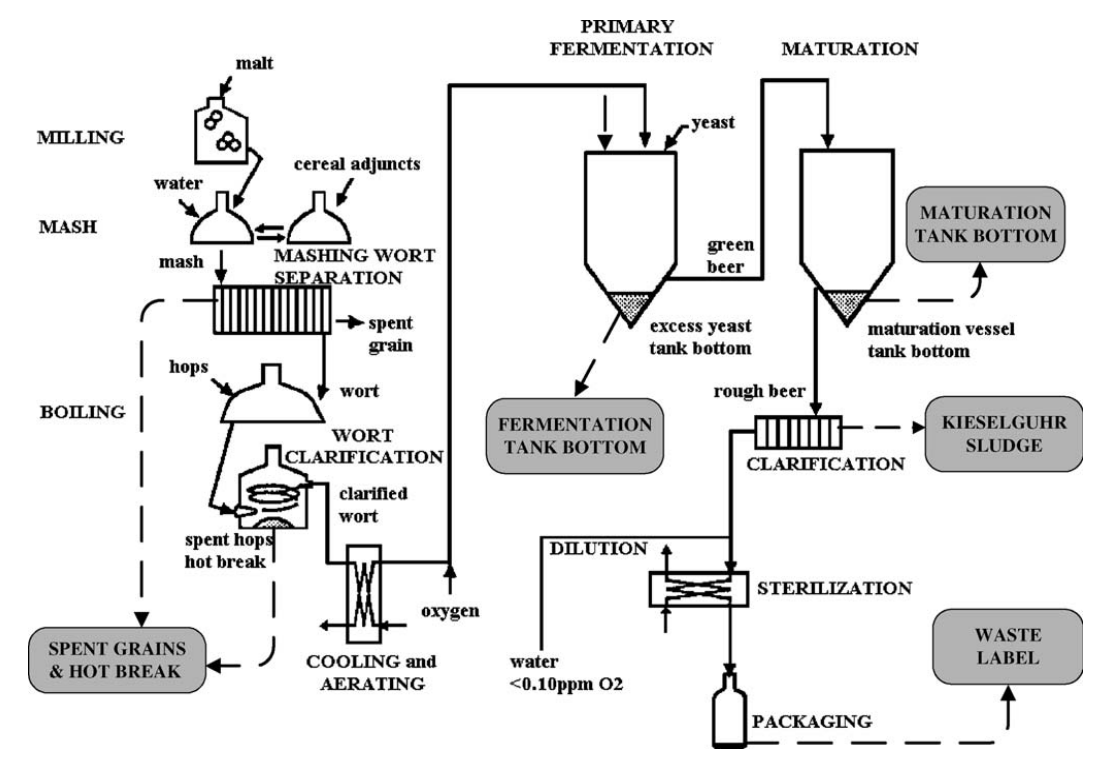

Figure 1. Brewing process and main wastes 


\section{Brewery wastewater treatment processes}

Biological wastewater treatment works on the principle of activity of bacteria and microorganisms living in their own organic matter can occur in the presence of oxygen, called aerobic process and in the absence of oxygen called anaerobic process. Most commonly used treatment system of agro-industrial wastewater is summarized in Figure 2 (Berni et al., 2014). Whatever the process or process combination is suitable for wastewater treatment methods are generally the following: Mechanical pretreatment with removal of large particles using rakes, sieves, grit chambers and preliminary sedimentation; Chemical-physical pre-treatment using neutralization and metering of chemicals; and Biological wastewater treatment such as Anaerobic pretreatment, Anaerobic-aerobic treatment and Aerobic treatment (Bodík, 2005; Asia et al., 2008). Anaerobic and aerobic biological treatment are widely applied. Previously, aerobic treatment has been applied for the treatment of brewery wastewater. However, recently anaerobic systems have become more attractive option. Because, the aerobic treatment of brewery effluent requires a comparatively large energy input compared to anaerobic treatment. During aerobic process, complex organic substances are completely oxidized to carbon dioxide, water, sulfate, phosphate and nitrate by a community of microorganisms dominated by heterotrophic bacteria and fungi. This produces large amounts of biomass (Kanagachandran and Jayaratne, 2006).

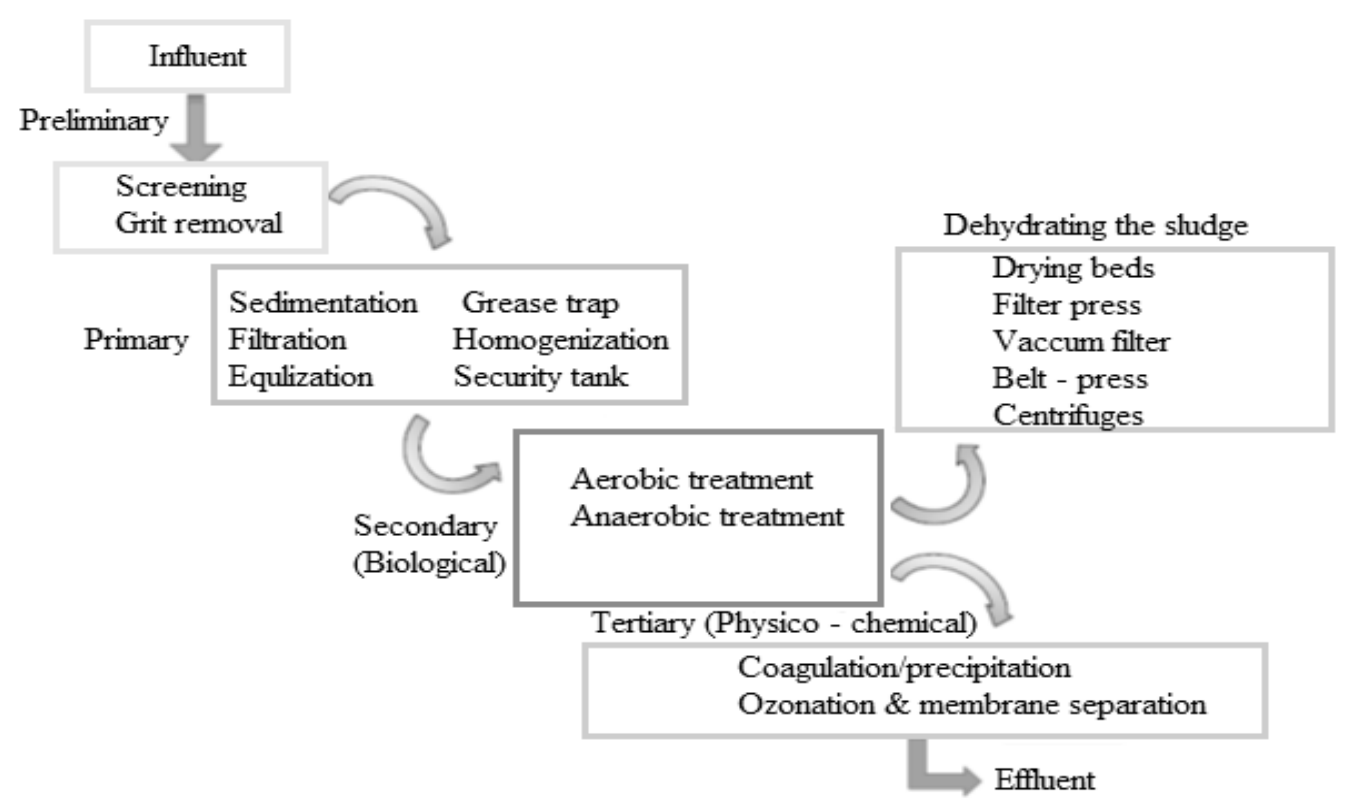

Figure 2. Scheme of agro-industrial wastewater treatment process

Brewery biomass (sludge) produced by aerobic, anaerobic, physicochemical, combined aerobic/physicochemical and combined anaerobic/physicochemical methods. Physicochemical method increases the quantity of sludge solids, thus making the sludge suitable for land reclamation. Whereas biological treatment methods (aerobic and anaerobic) can reduce the quantity of sludge before disposal. Processing and disposal of sludge is economic and environmentally friendly manner is currently of great importance to local authorities and industry. The disposal or reuse of sludge is a significant part of wastewater treatment program (Asia et al., 2008). 


\section{Sources of sludge}

Bio-solids/sludge's are nutrient rich organic matter solid residues generated from wastewater treatment plant (Sampson, 2016). Sludge is most commonly produced from secondary wastewater treatment plants. However, half of the solids suspended in wastewater are removed through primary treatment. The residual material from this process is a concentrated suspension called primary sludge, which will undergo further treatment to become bio-solids. Preliminary wastewater treatment (extracts of coarse solids by screening and other filtering devices) and tertiary (mainly chemical addition to clean the final effluent are called chemical sludge) wastewater treatment processes are also produce solid byproducts which are not incorporated in sludge or bio-solids (Şengün, 2007).

\section{Characteristics of sludge}

Environmental concerns regarding to land disposal of sludge causes surface-water and ground water pollution, contamination of soil and crops with toxic substances and transmission of human and animal diseases. Chemical analysis of a sludge shows that sludge consists of nitrates, ammonium and organic nitrogen, soluble and organic phosphate, potassium, heavy metals of cadmium, copper, nickel, lead and zinc, and selected organic compounds such as polychlorinated biphenyls (PCB) (Wendimagegn, 2016). Other chemical analysis on brewery sludge also revealed that it has high nitrogen, phosphorus, potassium, volatile fatty acids and nutrients which are important requirements for plant growth. Brewery sludge is also consisting of various important organisms like heterotrophic fungi and actinomycetes (Ramya et al., 2015).

In the present scenario, there is an increasing interest of recycling sludge's for agricultural application due to their valuable components such organic matter, nitrogen, phosphorus and other plant nutrients. However, the chemical properties of the sludge may be affected by the treatment process applied to wastewater and sludge (i.e., extent of industrial pretreatment, primary, secondary or tertiary wastewater treatment and chemicals used in the treatment, and method of sludge stabilization) and the original pollution load of the wastewater (Şengün, 2007).

Characterization of sludge is extremely important prior to sludge disposal or application to farm land because of associated risks of toxic elements accumulation in soil and potential health hazard of pathogens. The sludge physicochemical and biological content depend on the original pollution load of the treated water, treatment process applied to wastewater and sludge (Usman et al., 2012). The physicochemical and biological composition of brewery wastewater sludge is presented in Table 1.

\section{In sludge content of heavy metals}

The results of the BWS selected heavy metals indicates that the sludge can be used in farming since they are well below the EU standards as shown in Table 2. Trace elements of heavy metals are toxic in the living organisms even if they are not in large amounts under the natural systems. With the existence of the soil-plant system that helps in the reducing of the toxicity of the trace elements, there is negligible issues of health in humans as well as animals. Nonetheless, if the amounts are high and the concentrations of these heavy metals are high, there could be some problems such as toxicity of the soil and harmful effects to humans and animals. Cadmium, selenium, mercury, nickel, zinc and copper are come the metals that gives a huge anxiety when it 
comes to bio-solids. These trace elements are indispensable nutrients in the health of animals and plants and have less risks in small amounts due to their low solubility a sound aerated soil at 6.0 to $7.5 \mathrm{PH}$ (Şengün, 2007).

Table 1. Physicochemical and biological characteristics of brewer wastewater sludge

\begin{tabular}{|c|c|c|c|c|c|c|c|}
\hline Parameters & \begin{tabular}{|} 
Babel et al. \\
$(2009)$
\end{tabular} & $\begin{array}{c}\text { Alemu et al. } \\
(2017)\end{array}$ & $\begin{array}{l}\text { (Ediget, } \\
\text { 2016) }\end{array}$ & $\begin{array}{c}\text { Kanagchandra } \\
\text { and Jayarante } \\
(2006)\end{array}$ & $\begin{array}{c}\text { Erdem and } \\
\text { Sozudogu } \\
(2002)\end{array}$ & $\begin{array}{c}\text { Olowu et al. } \\
(2012)\end{array}$ & \begin{tabular}{|c}
$\begin{array}{c}\text { South Africa } \\
\text { pollutant limits } \\
\text { (class B) }\end{array}$ \\
\end{tabular} \\
\hline $\mathrm{pH}$ & 8.4 & 8.67 & 7.08 & 6.97 & 6.89 & 7.14 & - \\
\hline $\mathrm{TS}(\%)$ & 12.5 & - & 29.63 & - & - & - & - \\
\hline $\mathrm{TN}(\%)$ & 5.98 & 1.33 & 4.2 & 4.5 & 3.10 & - & - \\
\hline $\mathrm{TP}(\%)$ & 5.48 & 0.004 & 2.52 & 3.3 & - & - & - \\
\hline TK $(\%)$ & 0.92 & - & 106.4 & 0.2 & - & - & - \\
\hline $\mathrm{OC}(\%)$ & 269 & 3.5 & 31.12 & 27.1 & 42.5 & - & - \\
\hline $\mathrm{CEC}(\mathrm{meq} / 100 \mathrm{~g})$ & - & - & - & - & 47.4 & - & - \\
\hline $\mathrm{Cd}(\mathrm{mg} / \mathrm{kg})$ & 28 & 1.27 & 0.04 & Not detected & - & 1.23 & 85 \\
\hline $\mathrm{Cr}(\mathrm{mg} / \mathrm{kg})$ & 16 & 47 & 34.09 & - & - & 37.08 & 3000 \\
\hline $\mathrm{Cu}(\mathrm{mg} / \mathrm{kg})$ & 75 & 40 & 21.04 & 42 & - & 90.6 & 4300 \\
\hline $\mathrm{Pb}(\mathrm{mg} / \mathrm{kg})$ & 336 & - & 0.62 & 2.9 & - & 28.35 & 840 \\
\hline $\mathrm{Ni}(\mathrm{mg} / \mathrm{kg})$ & 7 & 31.33 & 13.93 & 17 & - & - & 420 \\
\hline $\mathrm{Zn}(\mathrm{mg} / \mathrm{kg})$ & 691 & 38.5 & 35.17 & 75 & - & - & 7500 \\
\hline $\mathrm{Hg}(\mathrm{mg} / \mathrm{kg})$ & 0.3 & - & 0.22 & Not detected & - & - & 55 \\
\hline $\mathrm{Fe}(\mathrm{mg} / \mathrm{kg})$ & - & 20.5 & 9642.14 & - & - & - & Not set \\
\hline $\mathrm{Mn}(\mathrm{mg} / \mathrm{kg})$ & - & 0.83 & 37.82 & 46 & - & - & No set \\
\hline $\mathrm{Co}(\mathrm{mg} / \mathrm{kg})$ & - & 33 & 0.77 & - & - & 7.10 & No set \\
\hline $\mathrm{Se}(\mathrm{mg} / \mathrm{kg})$ & - & 12.56 & - & - & - & - & 15 \\
\hline Mo (mg/kg) & - & 0.45 & - & - & - & - & 12 \\
\hline $\mathrm{Na}(\mathrm{mg} / \mathrm{kg})$ & - & - & 101.08 & - & - & - & - \\
\hline $\mathrm{Ca}(\mathrm{mg} / \mathrm{kg})$ & - & - & 40.0 & - & - & - & - \\
\hline $\mathrm{Mg}(\mathrm{mg} / \mathrm{kg})$ & - & - & 11.34 & 1106 & - & & - \\
\hline $\begin{array}{l}\text { Pathogens (fecal } \\
\text { coliforms), PN/g }\end{array}$ & $5.6 \times 10^{2}$ & - & $5 \mathrm{cfu}$ & - & - & - & $\begin{array}{c}<10^{2} \mathrm{MPN} / \mathrm{g}, \\
\mathrm{EPA}, \text { class A } \\
\text { standards } \\
\end{array}$ \\
\hline
\end{tabular}

Table 2. Analysis result of heavy metal in BWS

\begin{tabular}{c|c|c|c|c|c|c}
\hline Parameters & $\begin{array}{c}\text { Lead, Pb } \\
(\mathbf{m g} / \mathbf{k g})\end{array}$ & $\begin{array}{c}\text { Cadmium, Cd } \\
(\mathbf{m g} / \mathbf{k g})\end{array}$ & $\begin{array}{c}\text { Mercury, Hg } \\
(\mathbf{m g} / \mathbf{k g})\end{array}$ & $\begin{array}{c}\text { Nickel, Ni } \\
(\mathbf{m g} / \mathbf{k g})\end{array}$ & $\begin{array}{c}\text { Chromium, Cr } \\
(\mathbf{m g} / \mathbf{k g})\end{array}$ & $\begin{array}{c}\text { Cobalt, Co } \\
(\mathbf{m g} / \mathbf{k g})\end{array}$ \\
\hline BWS & $0.62 \_0.01$ & $0.04 \_0.01$ & $0.22 \_0.01$ & $13.93 \_0.00$ & $34.09 \_0.00$ & $0.77 \_0.02$ \\
\hline
\end{tabular}

\section{Brewery sludge nutrient content}

In Table 3, the sludge of the brewery was seen to be virtually neutral. The normal range of the brewery sludge $\mathrm{PH}$ is between 6.5 and 11.5 (Luque et al., 1990). Various disparities in the treatment of the wastewater in the plants and the raw water attributes to the differences in the PH observed. The Organic carbon of the control soil was $1.5 \%$ while that of the sludge was $31.12 \%$ showing a great improvement. The BWS Soil parameters on the other hand attributes to the high-water holding capacity. Greater potential of cation exchange capacity, more organic matter, and other nutrients. has investigated that BWS amendments enhanced $\mathrm{pH}$ of acidic soils and improved the organic carbon, exchangeable cations, soluble cations and anions (Luque et al., 1990) 
Table 3. Brewery sludge plant nutrient parameter results

\begin{tabular}{|c|c|c|c|c|c|c|c|c|c|c|c|c|c|c|}
\hline 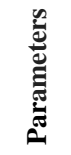 & 跑 & 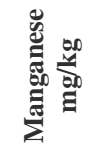 & 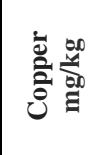 & 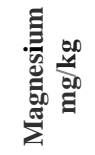 & 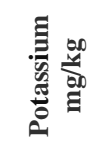 & 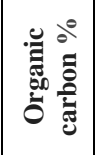 & 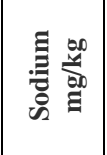 & 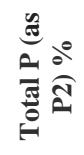 & : & 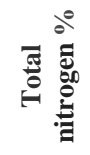 & 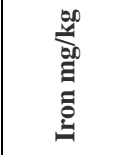 & 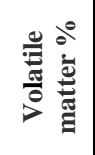 & 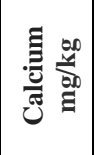 & 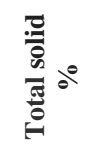 \\
\hline WS & $\begin{array}{c}7.08 \pm \\
0.06 \\
\end{array}$ & $\begin{array}{c}37.82 \pm \\
0.04\end{array}$ & $\begin{array}{c}21.04 \pm \\
0.04\end{array}$ & $\begin{array}{c}11.34 \pm \\
0.30\end{array}$ & $\begin{array}{c}106.40 \pm \\
1.41\end{array}$ & $\begin{array}{c}31.12 \pm \\
10.27 \\
\end{array}$ & $\begin{array}{c}101.08 \pm \\
0.25 \\
\end{array}$ & $\begin{array}{c}2.52 \pm \\
0.28 \\
\end{array}$ & $\begin{array}{c}35.17 \pm \\
0.01\end{array}$ & \begin{tabular}{|c|}
$4.20 \pm$ \\
0.21 \\
\end{tabular} & 2.9 & \begin{tabular}{|c|}
$54.23 \pm$ \\
0.96 \\
\end{tabular} & \begin{tabular}{|c|}
$40.00 \pm$ \\
0.57
\end{tabular} & $\begin{array}{c}29.63 \pm \\
0.68\end{array}$ \\
\hline Soil & $\begin{array}{c}7.15 \pm \\
0.02 \\
\end{array}$ & - & $\begin{array}{c}0.45 \pm \\
0.01\end{array}$ & $\begin{array}{c}12.72 \pm \\
0.37\end{array}$ & $\begin{array}{c}66.44 \pm \\
0.37\end{array}$ & $\begin{array}{c}1.56 \pm \\
0.06\end{array}$ & $\begin{array}{c}19.20 \pm \\
00.28\end{array}$ & $\begin{array}{c}0.56 \pm \\
0.03 \\
\end{array}$ & $\begin{array}{l}1.25 \pm \\
00.00\end{array}$ & $\begin{array}{c}1.96 \pm \\
0.03\end{array}$ & $\begin{array}{c}25.05 \pm \\
0.22\end{array}$ & . & $\begin{array}{c}33.13 \pm \\
0.03\end{array}$ & - \\
\hline
\end{tabular}

\section{Sludge treatment methods}

Sludge treatment techniques: Sludge must be processed for economic and hygienic reasons. Sludge processing reduces the volume, stabilize the sludge, remove water and kill pathogenic organisms. There are different sludge treatment techniques, such as thickening, conditioning, dewatering and stabilization. Figure 3 shows that the possible sludge treatment processes, each treatment effect on the sludge and how that treatment techniques may affect the sludge application to land. Reducing sludge volume is an important thing which helps to limit its handling and transporting costs. There are series of constructive sludge treatment technologies possible to reduce sludge volume up to $2 \%$ of the initial volume. Mechanical and thermal dewatering increases the concentration of dry solids from $2 \%$ up to $90 \%$, making the dried and stabilized sludge ready for easy storage and reuse as soil conditioner or fertilizer, depending on its composition. When sludge physicochemical composition does not allow for agricultural reuse, the best alternative option is sludge destruction by incineration. Since sludge contains energy which can be recovered either by digestion in anaerobic reactors to produce biogas or by incineration which generates heat and can be used as thermal energy for sludge drying process and transformed into steam for electricity production. Sludge treatment has generally the following advantages: Reduction of pathogens: Reduce the excess sludge mass and handling cost, improve rheological, mechanical and biological properties of the waste sludge, prevent fermentation and odor problems and Improve soil physical properties such as porosity, water retention and stability. (www.waterleav.com)

\section{Thickening}

Sludge generated from wastewater treatment plant contains lots of water and it has to be thickened to reduce the volume and make some of its water free. Thickening is the process of increasing solids content of sludge by the removal of a proportion of its liquid content. Gravity thickening is the simplest and least expensive process for thickening sludge (Garg and Tanyimboh, 2009). Sludge treatment systems are usually physical in nature. They include gravity settling, floatation, centrifugation, and gravity belts (Hänel, 1988).

\section{Conditioning}

This method involves modification of the sludge structure by removing more water from it. This method can improve thickening, and dewatering. Chemical method is one of the conditioning system which uses mineral agents like lime or salts or an organic 
compound to remove the water content. Thermal method is another method in which sludge is heated to $150-200{ }^{\circ} \mathrm{C}$ for $30-60 \mathrm{~min}$. It involves the chemical or physical treatment of sludge to enhance its dewatering characteristics. The most applied conditioning systems are the addition of chemicals and heat treatment. Other conditioning processes include freezing, irradiation and elutriation (Garg and Tanyimboh, 2009).

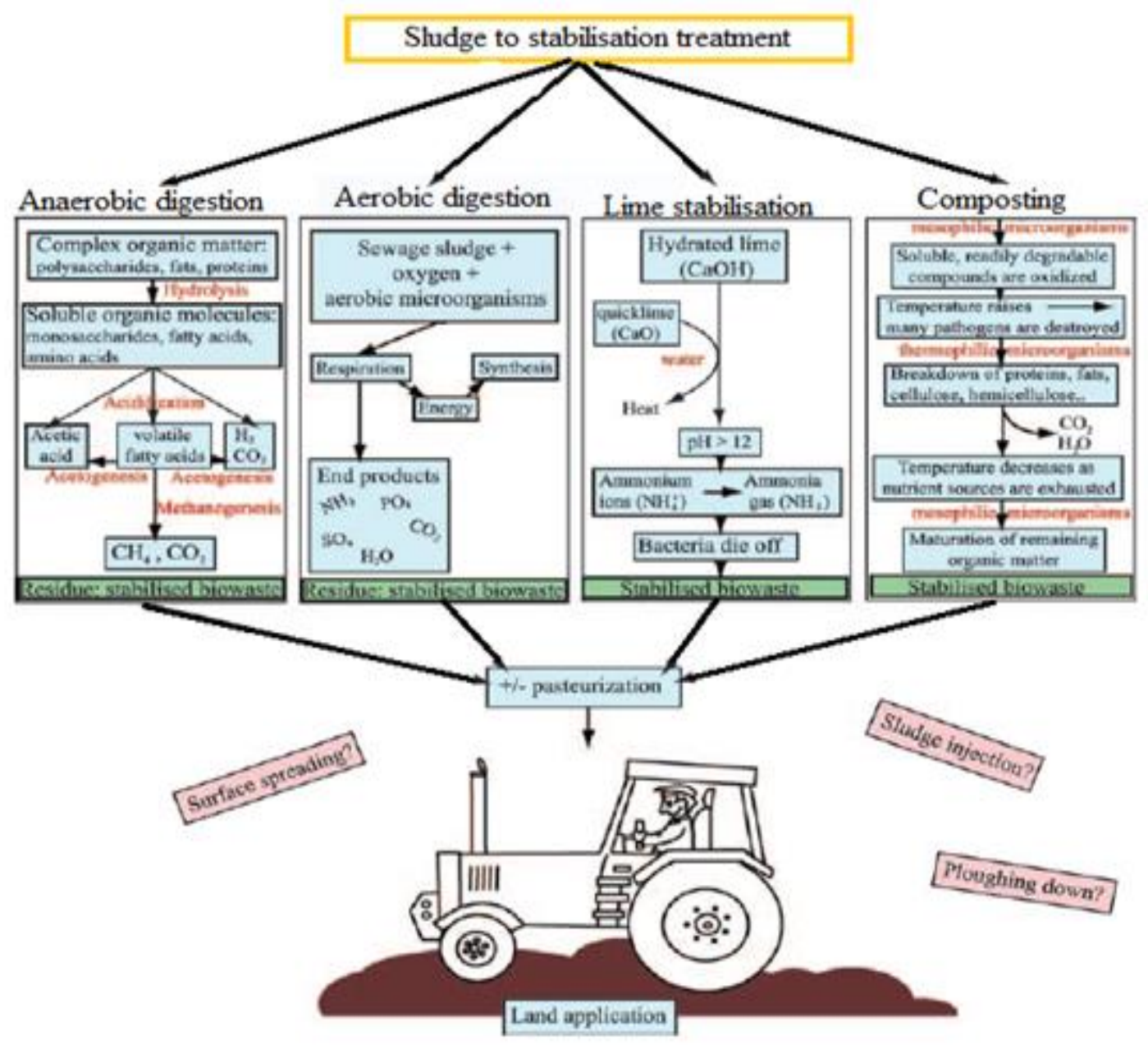

Figure 3. Flow chart of sludge treatment steps with the view to yield an end by product with high microbial quality for subsequent use as a crop fertilizer. (Source: Arthurson, 2008)

\section{Stabilizing}

Sludge stabilization is necessary to reduce pathogen content, eliminate offensive odors and reduce or eliminate the potential for putrefaction. Technologies that used for stabilization of sludge are liming, heat treatment aerobic digestion, anaerobic digestion and composting (Fig. 3) (Garg and Tanyimboh, 2009). Because, these treatment systems reduce the organic matter content, water content, emission of unpleasant odors and concentration of pathogenic micro-organisms. Anaerobic digestion of sludge at mesophilic $\left(30-38{ }^{\circ} \mathrm{C}\right.$ ) and thermophilic $\left(50-60{ }^{\circ} \mathrm{C}\right)$ is used to inactivate pathogens. 
Thermophilic treatment is more efficient in minimizing the content of pathogenic bacteria and parasites than mesophilic. Thermophilic treatment sludge fulfils class A bio-solids results from sludge digestion at $60-75^{\circ} \mathrm{C}$ which has low pathogen content compared to class B bio-solids, hence class A bio-solids can be used for unrestricted public contact. Whereas, class $\mathrm{B}$ results from mesophilic sludge digestion at $28-38{ }^{\circ} \mathrm{C}$, contains fecal coliform density as an indication of pathogenic level. The major advantage of anaerobic digestion is to generate biogas as an end product that used for the treatment facility. Aerobic digestion process is performed by aerobic microorganisms and generates heat. However, this stabilization does not reduce the pathogen content to the acceptable standards for unrestricted use of sludge in agriculture. This indicates that sludge should be under go additional stabilization step to achieve a product with sufficiently high microbial quality to enable recycling of residues. Some of sludge stabilizing methods are pasteurization (heated at temperature $70-80{ }^{\circ} \mathrm{C}$ ) (Arthurson, 2008).

\section{Dewatering}

This is mainly useful to reduce the volume of the sludge via water separation. In this process, it is possible to remove a certain proportion of free, adhered and capillary water with the technology available technology. Among these processes; drying beds, centrifuging, filter belt and filter press. All process except drying beds, other process requires addition of a chemical conditioning agent (Sullivan, 2015). Dewatering is a vital step in sludge treatment processes. In this process, belt filter press and/or a centrifuge are mostly applied (Evans, 2008). Dewatering process is a physical unit operation used in reducing the moisture content of sludge. This process is not incinerated, but achieved by applying sand beds or by mechanical dewatering equipment. Selection of appropriate sludge dewatering technique depends upon the nature/characteristics of the sludge to be dewatered, available space, and moisture content requirements of the sludge cake for ultimate disposal. Sludge dewatering may also be improved by chemical conditioning such as addition of polymer. However, if land is available and sludge quantity is small, natural dewatering techniques such as drying beds and drying lagoons are most attractive (Garg and Tanyimboh, 2009).

\section{Sludge disposal methods}

Sludge disposal without treatment changes public perceptions and legislation of worldwide to make disposal to landfill less popular. Due to this issue, in many countries agricultural use of sludge is becoming more attractive for sustainability. There are different sludge disposal methods such as landfill, incineration, and land application. Among these, incineration end product is not sustainable for beneficial use (Şengün, 2007).

\section{Landfill}

Landfill system is the simplest solution to handle sludge by concentrating the material in a single location. This disposal system causes bio-sludge borne pollutants and pathogens to ecosystems and humans if landfill is not properly constructed and maintained. Landfill is economically feasible disposal options, but it is risky. Buried organic matters undergo anaerobic decomposition which produces methane gas. This gas is a greenhouse gas and causes global warming. Therefore, there is a need to collect at some landfills and utilize the energy content. On the other hand, the chemicals and 
nutrients can pose risk to local groundwater from older landfills if it does not have synthetic liners that protects seepage. Pathogen content in sludge has also a risk and additionally, the potential content of organic matter and plant nutrients in the sludge will be lost with landfilling (Şengün, 2007).

\section{Incineration}

This process is one of most expensive method and working by burning of sludge at high temperatures in a closed device in order to reduce the sludge volume, kills pathogens and destroys most organic chemicals, but this disposal method requires extra energy for safe disposal of the resulting ash. The end product of incineration, i.e., ash is a stable inorganic material containing $10-20 \%$ of the original solids. The associated problem with this method is that it does not destroy trace elements rather than concentrating them in the ash. Beside this, it also produces carbon dioxide which also a greenhouse gas causes global warming and lose of beneficial plant nutrients and organic matter for plant. The aim of integrated sludge treatment is to maximize the intrinsic value of sludge in its volume reduction processes. Depending on the type of sludge characteristics, one or more sludge treatment steps are used to optimize the sludge volume.

\section{Land application}

Land application of sludge is an alternative to landfilling or incineration because of the negative environmental impacts and high costs of sludge management practices. The high organic and nutrient content of the sludge makes it a valuable resource for farmers as it increases soil quality and crop yields and decreasing the need for expensive chemical fertilizer costs (Stout, 2002). Land application of sludge is less expensive and can improve the structure of the soil as fertilizer by supplying nutrients to crops and other vegetation's grown in the soil. Application of sludge that contains organic matter can improve the physical, chemical and biological properties of the soil. Because presence of organic matter can increase water infiltration, reduce soil erosion, increase water holding capacity, reduce soil compaction and increase soil granulation, increase the ability of soil to retain nutrients and provide nutrients for plant growth and food and energy for beneficial microorganisms. All of these beneficial properties make sludge considered a good choice for homeowners, landscapes, farmers and foresters. One type of sludge application as organic fertilizer is more commonly in the form of dried and/or pelletized. Producing sludge in this form is complex and expensive, however, dried sludge are often blended with other materials and marketed as an organic fertilizer with balanced nutrient levels. However, agricultural use of these sludge showed a great variability over time depending on weather conditions and crop type. Therefore, scheduling sludge transport and application are compatible with agricultural planting, harvesting and possible adverse climatic conditions requires careful management (www.waterleav.com, 2017).

\section{Factors affecting land application of sludge}

\section{Bio-solids}

Contain significant amounts of macro- and micronutrients which are economically attractive for land application. Bio-solids are rich in organic matter and essential plant nutrients which can be utilized as soil conditioner and fertilizer through the contribution of organic matter and as a fertilizer by supplying essential micro- (zinc, copper and iron) 
and macronutrients (nitrogen, phosphorus and potassium) that increase the plant growth and productivity, improve soil quality, water holding capacity, air and water transport. The slow release of nutrients prevents leaching of excess plant available nutrients and possible contamination of ground and surface water (Wendimagegn, 2016). The only drawbacks of the use of sludge on agricultural land application is its pollutant load including heavy metals, organic compounds, and pathogens. The potential toxic elements such as cadmium, copper, nickel, lead, zinc, mercury and chromium concentrated in the sludge as a result of their association with settable solids during primary and secondary treatment processes (Usman et al., 2012).

\section{Heavy metals}

Trace elements are elements that exists in natural systems in small amounts and when they present in excessive concentrations they become toxic to living organisms. The plant-soil system has its own protective mechanisms that limits the potential toxicity of trace elements in their areal portions and these minimizes health problems of animals and humans. However, excessive accumulation of these trace elements in plants can cause either reduced yields or health problems to animals or humans that ingest the plants. Toxicity of heavy metals to plant species depends on their concentration in the soil. Some potentially toxic heavy metals may occur at increased levels in the food chain. There are two concerns regarding to trace element additions to agricultural soil amendment might become toxic to crops and sufficiently concentrated in an edible crop to have harmful effects on an animal or human that consumes it. Cadmium, copper, mercury, molybdenum, nickel, selenium and zinc are the greatest concern in bio-solids. In fact, many of these trace elements are essential nutrients for plant and animal health. These metals cause little hazard to crop production or plant accumulation because of their low solubility at pH 6.0 to 7.5 in a well aerated soil where field crops are typically grown or are present in bio-solids in small quantities (Şengün, 2007).

\section{Organic contaminants}

In line with presence of beneficial organic matter, bio-sludge also may contain toxic organic contaminants. Particularly, those organic substances that do not decompose will likely be strongly adsorbed onto the organic matter particles present in bio-solids. Sludge does not only contain urine or faces from human but also contain hormones and pharmaceutical substances that could possibly constitute a risk of influencing the microflora of the land. Sludges may contain synthetic organic chemicals from industrial wastes, household products and pesticides. These chemicals may be volatilized, degraded, sorbed to sludge or discharged in the aqueous effluent. Degradation results in the formation of other products that can be toxic or less toxic than the original compounds (Şengün, 2007).

\section{Salts}

Different kinds of salts can be present in bio-solids which can cause an effect to seed germination or growth of young plants through accumulation in the root zone of the soils. Soluble salts are not expected to be a problem with agronomic rates of bio-solids that used for soil amendment of disturbed land, because leaching by rainfall will remove excess amount of salt from the root zones. However, large rate application of bio-solids is contributing high salt discharges to the sewer system (Şengün, 2007). 


\section{Pathogens}

As sludge vary in quality and quantity of its organic and inorganic content, it also varies in the type and number of pathogens it contains. In sewage sludge and similar wastes, most of the pathogens will be hazard, but a few salmonella typhi, E. coli and some mycobacteria have a higher rating of hazard. Bacteria, viruses, protozoa and parasitic worms are disease causing pathogens. These pathogens can present a public health hazard if they are transferred to food crops grown on land to which bio-sludge are supplied and contained in runoff to surface waters from land supplied sites. Advanced and conventional sludge treatment systems produce a stabilized final product where such organisms are unlikely to multiply to large numbers and problems arising from bacterial toxins during sludge storage or application (Şengün, 2007).

\section{Objective}

The objective of this review paper is to discuss and summarize the characteristics, treatment techniques, fertilizer potential and other available management options of breweries sludge generated from wastewater treatment plants.

\section{Materials and methods}

This review paper was written using searching key phrases "Brewery sludge generation", "Sludge chemical composition", "Brewery sludge disposal", "Brewery sludge treatment" and "Brewery sludge management" in Springer link, science direct, library genesis, jester, and www.nap.org searching web pages. From these searching, peer reviewed journals, review papers and MSc. Thesis were used. The interpretation of the result of each document was done using bar graphs, lines and scatter plot in a Microsoft excel. Result measurement units of sludge physicochemical parameters investigated by different scholars were reorganized and expressed in similar units for comparison.

\section{Results and discussion}

\section{Characteristics of $B W W S$}

\section{BWWS amended with clay loamy soil}

According Remya et al. (2015), the brewery wastewater sludge (BWWS) were characterized and tested for chilly seed germination. Plant growth trials were conducted to evaluate the application of BWWS as organic fertilizer. This brewery wastewater sludge was amended with clay loamy soil in different proportion of soil to BWWS with controls. The physicochemical characterization result showed that the $\mathrm{pH}$ of the sludge alone and its composite ranges almost neutral (i.e., 6.08-7.62).

The brewery sludge is also shows a rich source of nitrogen, and potassium were very high, i.e., $420.25 \mathrm{~kg} / \mathrm{ha}$ and $840.0 \mathrm{~kg} / \mathrm{ha}$ respectively as compared to the clay loamy soil. On the contrary to nitrogen and potassium increased application of sludge decreased the availability of phosphorus. Figure $4 a, b, c$ and $d$ indicates that the levels of nitrogen, phosphorus, potassium, organic carbon, electrical conductivity, and $\mathrm{pH}$ in clay loamy soil amended with brewery sludge (Ramya et al., 2015). 


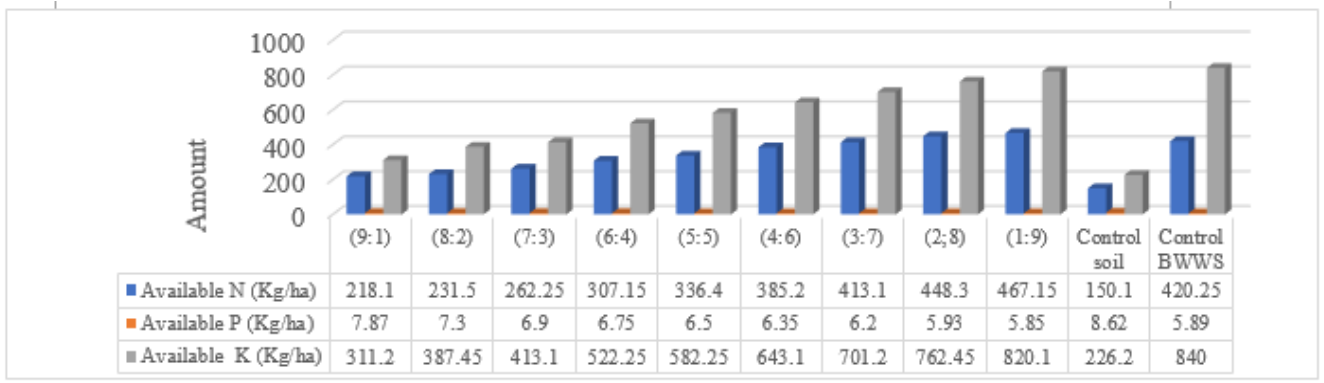

(a)

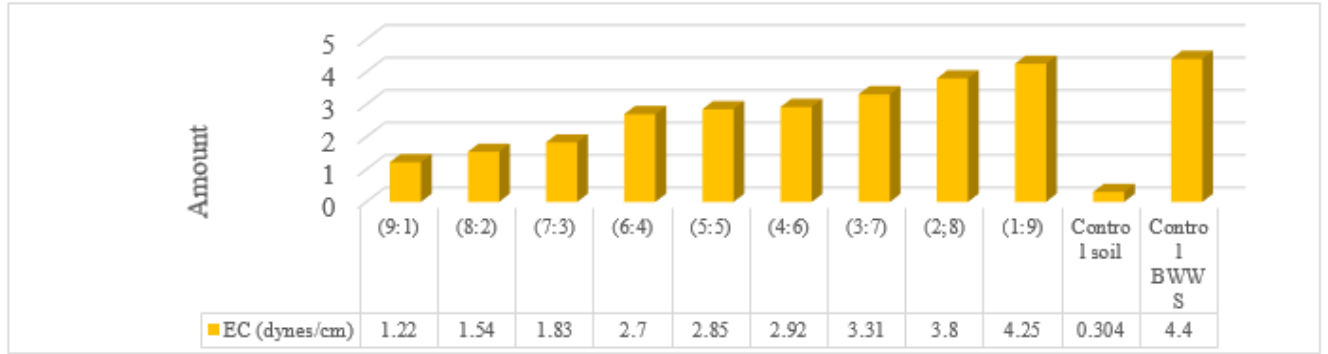

(b)

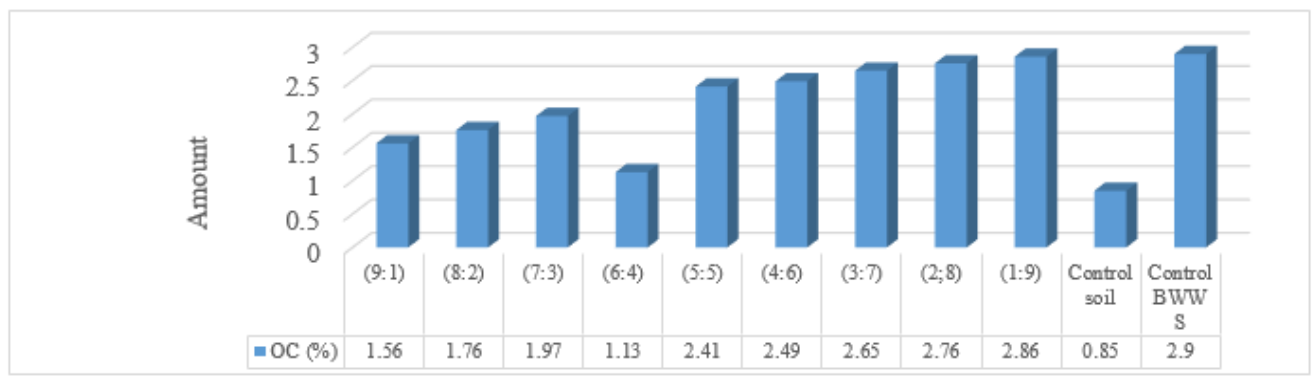

(C)

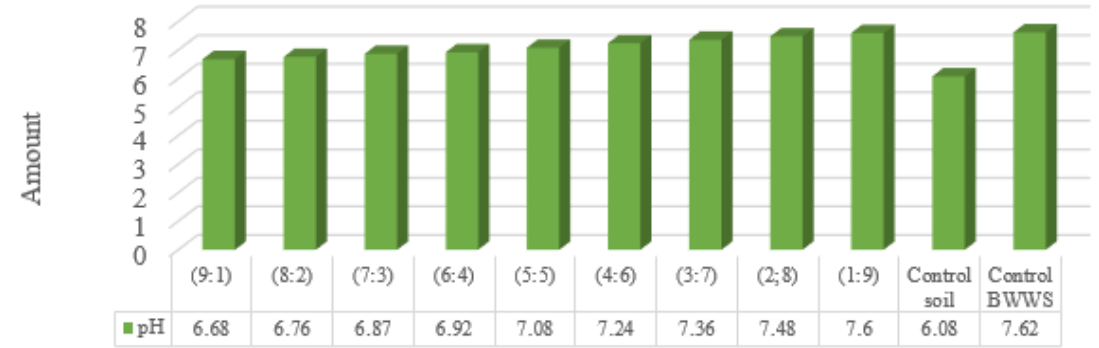

(d)

Figure 4. $a, b, c$ and $d$ : Levels of $N, P, K, O C, E C$ and $p H$ in clay loamy soil amended with $B W W S$

From Figure 4 the percentage of organic carbon of the sludge was 2.90, which is greater than all composite and control values (clay loamy soil). This may be due to addition of brewery sludge that improve the organic carbon content of the clay loamy soil significantly and the higher water retention capacity is linked to the high organic matter, high cation exchange capacity and other nutrients.

Analysis of heavy some selected heavy metals $(\mathrm{Pb}=0.004 \%, \mathrm{Ni}=0.0024 \%$, $\mathrm{Hg}=$ below detection limit, and $\mathrm{Cd}=$ traces) in BWWS were present below the standard levels and the sludge can be safely used for agricultural application (Ramya et al., 2015). 
Similar research investigation by Erdem and Ok (2002) also proves that brewery sludge amendments improved the carbon and nitrogen content of the soil. Organic carbon content of the amended soil was increased as the BWWS loading rates were increased. The total nitrogen has also indicated the increasing trend with the addition of BWWS for all incubation periods. Whereas, the $\mathrm{pH}$ and salinity of soil shows fluctuations. The $\mathrm{pH}$ of amended and un-amended soil samples decreased with the incubation time. The decreased $\mathrm{pH}$ values could be explained by organic acids produced during nitrogen mineralization and release of soluble electrolytes such as nitrates and sulfates in the soil solution. While salinity increment arises from addition of BWWS, which does not at a level to affect the yield of sensitive crops. The increment of organic carbon and nitrogen content of the amended soil as brewery sludge loading rates increased was indicated in Figure 5 (Erdem and Ok, 2002).

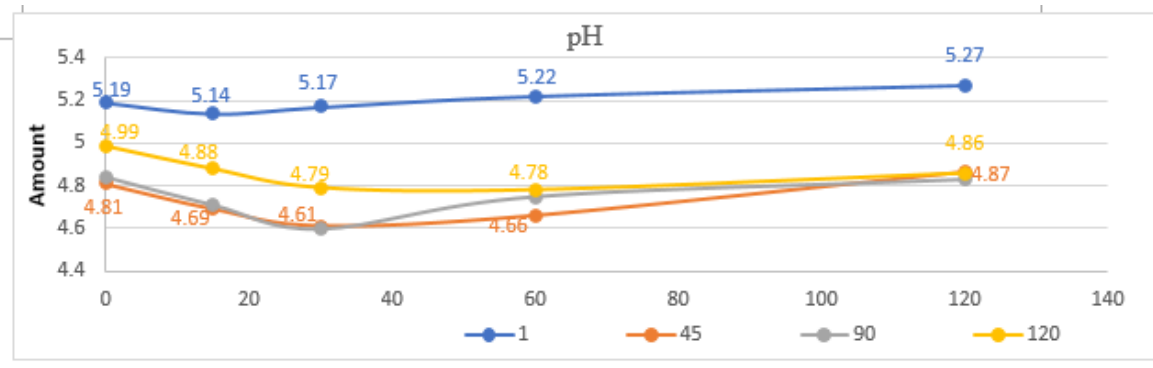

(a)

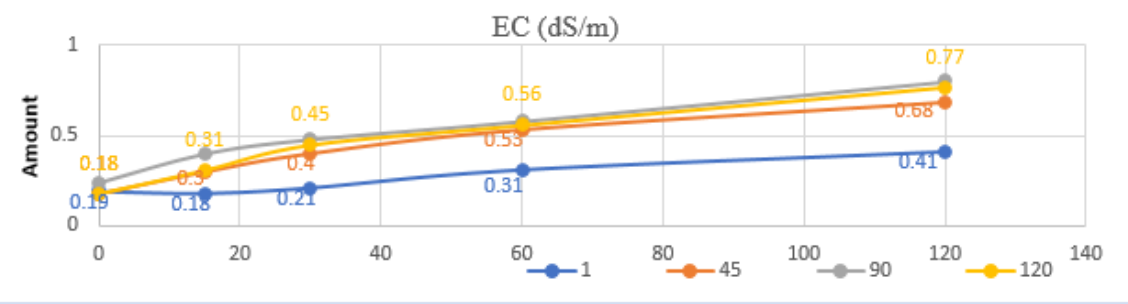

(b)
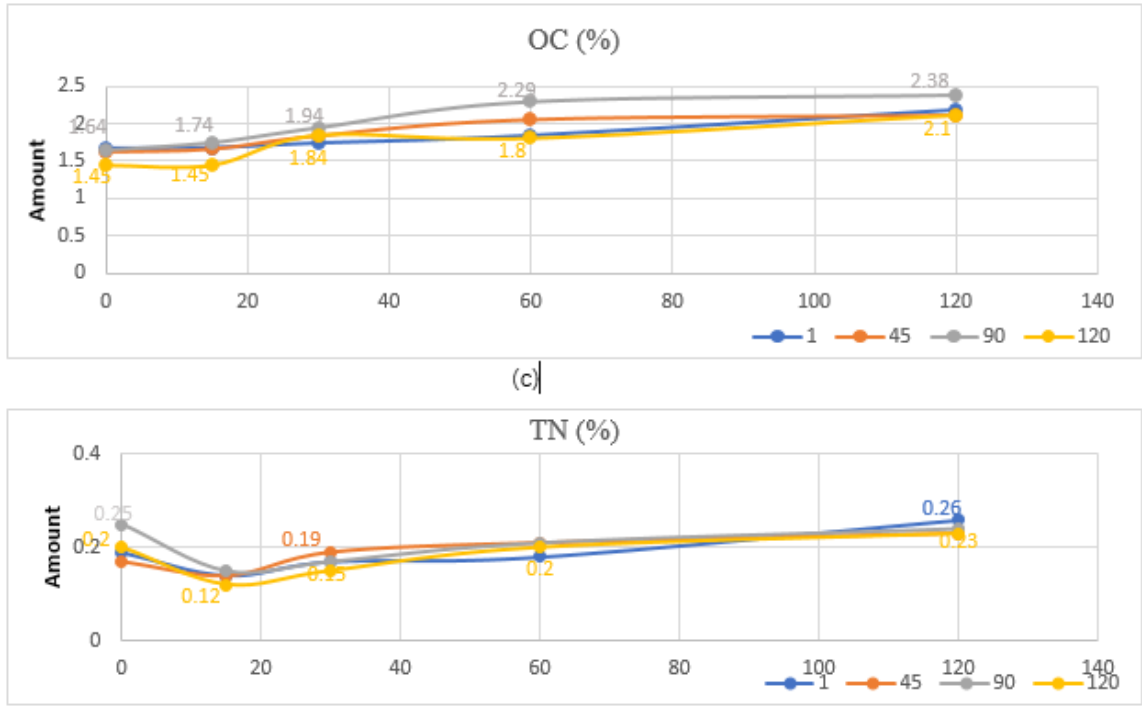

(d)

Figure 5. $a, b, c$ and $d$ : Changes in some chemical characteristics of BWWS addition on soil sample 


\section{Physicochemical properties of dried (brewery waste sludge) BWWS}

Kanagachandran and Jayaratne (2006) investigates the brewery wastewater sludge potential application as an organic fertilizer alone and with combination of municipal solids and farm solids for germination of pumpkin seeds. Before the pilot scale trial was conducted, sun dried brewery wastewater sludge (denoted as BWS), mixtures of BWS with municipal solids (denoted as compost A) and farm solids (denoted as compost B) were analyzed for both chemical and physical parameters. The results of physicochemical characteristics of BWS, Compost A and Compost B are explained in graph (Fig. 6).

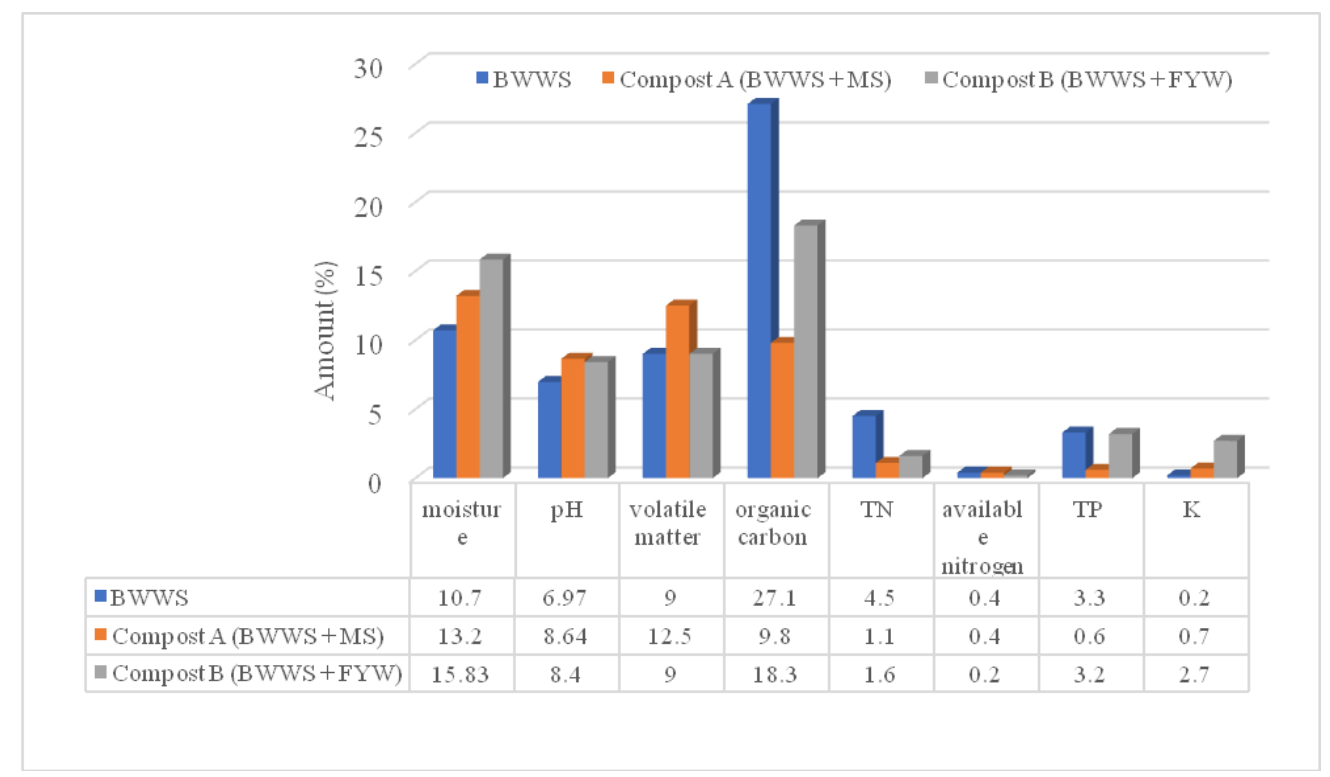

Figure 6. Physicochemical properties of dried BWWS, Compost A and Compost B

The $\mathrm{pH}$ of (Brewery waste sludge) BWWS investigated by Kanagachandran and Jayaratne (2006) was approaches to neutral whereas compost A and compost B appeared under alkaline conditions. This may be due to the differences in the presence of mixtures of other substrates in BWWS. The total nitrogen and organic content of BWWS was higher than compost A and compost B which are derived from municipal wastes and farm yard wastes. This has a vital role in plant nutrition and ecosystem functioning. The total phosphorus content of BWWS was equivalent to farm yard compost. While, potassium, and the micronutrients manganese, copper and zinc contents were lower in BWWS compared to both composts. Water holding capacity is one of the valuable property and important in soil for releasing humidity to the plants when they require. The water holding capacity of BWWS was the highest compared to compost $\mathrm{A}$ and compost $\mathrm{B}$. This property may be linked to the high content of organic matter and nutrients. Presence of heavy metals is one of the main hurdle in the agricultural application of wastewater sludge because of their toxic effects on crops and soil and the leaching of heavy metals into the nearby water sources.

The concentration of metals in (Brewery waste sludge) BWWS, compost A and compost B are explained in Figure 7. The analysis of heavy metals in BWWS revealed that the level of lead and nickel were lower than the expected Sri Lankan standards for organic fertilizer which are $250 \mathrm{mg} / \mathrm{kg}$ and $100 \mathrm{mg} / \mathrm{kg}$, respectively. 


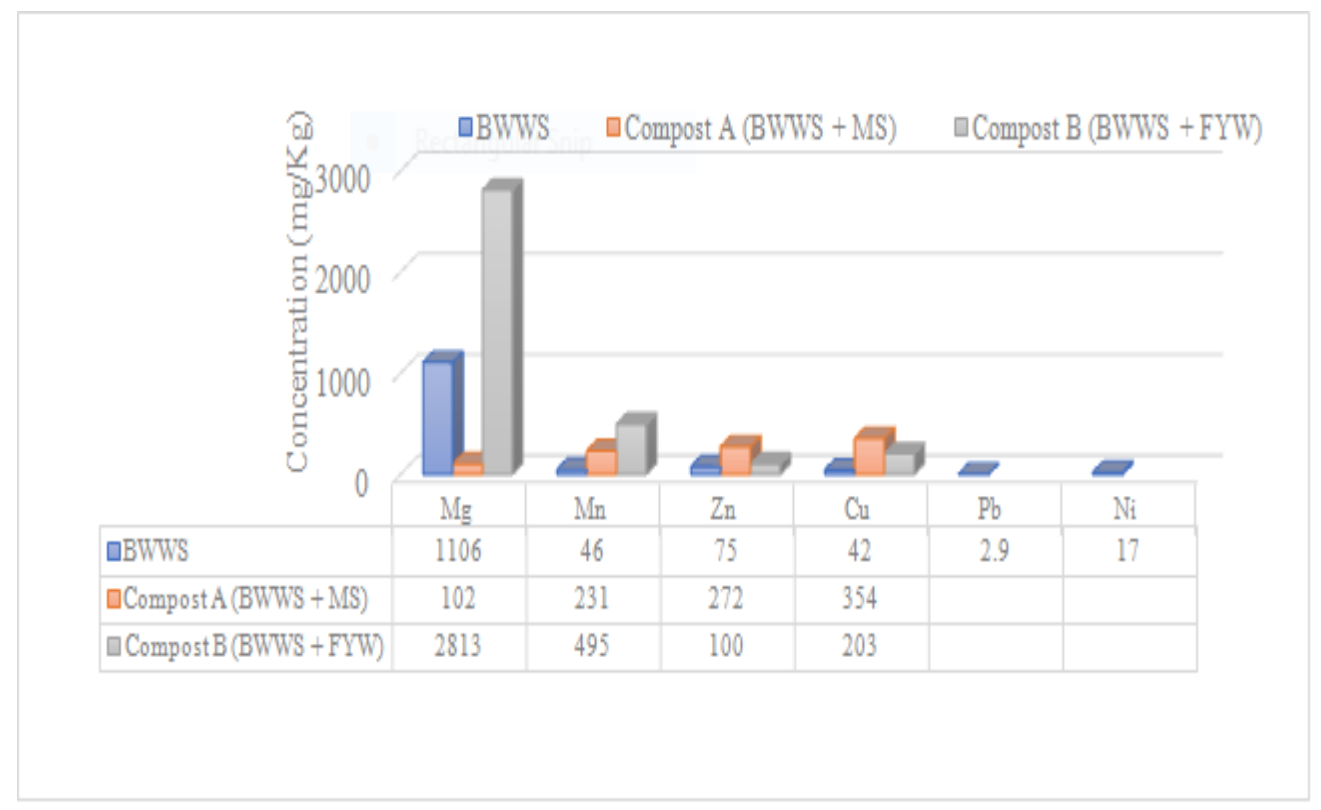

Figure 7. Content of minerals in BWWS, Compost $A$ and Compost $B$

\section{The effects and potential of brewery sludge (BWWS) as application of organic fertilizer}

\section{Effects on treatment of acidic soils and heavy metals}

Dessalew et al. (2017) also tried to analyze the effect of BWSS on the treatment of acidic soils and there result showed that the $\mathrm{PH}$ of BS samples presented alkalinity that ranged from 8.79 in fresh BS to 8.37 in a two-year old sample as shown in Table 4 . According to Luque et al. (1990), alterations in the source of water and processing method can create a difference in PH as shown from the South American breweries which gave their PH oscillating from 6.5 to 11.5. Using BS as a method of modifying the soil can alter the micronutrients and macronutrients availability. Therefore, combination of BS with some other compounds can help in lowering the PH values. Conversely plants that can endure alkalinity can be used in such cases.

Since about $40 \%$ of the cultivated land in Ethiopia have soils that are acidic (Mesfin, 2007), then BSDS can be utilized so as to make the fertility of the soil to be better. Additionally, since there is decline of PH of BS with age, then the aged BSDS can be useful in impartial or alkaline soils (Dessalew et al., 2017).

Table 4. Physicochemical analysis of the brewery waste sludge (BWWS)

\begin{tabular}{c|c|c|c|c|c|c|c|c|c|c}
\hline \multicolumn{2}{c}{ Parameters } & $\begin{array}{c}\text { Organic } \\
\text { carbon } \\
\left(\mathbf{g ~ k g}^{-1}\right)\end{array}$ & $\begin{array}{c}\text { Total } \\
\text { nitrogen } \\
\left(\mathbf{g ~ k g}^{-1}\right)\end{array}$ & $\begin{array}{c}\text { P } \\
\left(\mathbf{m g ~ k g}^{-1}\right)\end{array}$ & $\begin{array}{c}\text { Total P } \\
\left(\mathbf{m g ~ k g}^{-1}\right)\end{array}$ & $\begin{array}{c}\mathbf{k} \\
\left(\mathbf{m g ~ k g}^{-1}\right)\end{array}$ & $\begin{array}{c}\text { Zn } \\
(\mathbf{P P M})\end{array}$ & $\begin{array}{c}\text { Cu } \\
(\text { PPM) }\end{array}$ & $\begin{array}{c}\text { Porosity } \\
(\%)\end{array}$ & pH \\
\hline \multirow{2}{*}{$\begin{array}{c}\text { Age of } \\
\text { brewery } \\
\text { sludge }\end{array}$} & $\begin{array}{c}\text { Fresh } \\
\text { brewery } \\
\text { sludge }\end{array}$ & 309 & 22 & 415.91 & 1664.98 & 3296.88 & 33.19 & 25.19 & 71.61 & 8.79 \\
\cline { 2 - 11 } & $\begin{array}{c}\text { Two } \\
\text { months }\end{array}$ & 108 & 8 & 416.29 & 4069.76 & 1676.05 & 33.03 & 25.08 & 77.27 & 8.51 \\
\cline { 2 - 11 } & Two years & 106 & 7. & 373.22 & 5475.43 & 882.58 & 33.02 & 25.01 & 72.83 & 8.37 \\
\hline
\end{tabular}


Khan et al. (2014), found that the soil (control) and brewery sludge are slightly acidic in nature. Nitrogen, phosphorus, potassium and heavy metals $(\mathrm{Zn}, \mathrm{Cu}, \mathrm{Cd}, \mathrm{Pb}$, and $\mathrm{Cr}$ ) content in brewery sludge were higher than the soil. The characteristics of soil and brewery sludge are presented in Table 5. Importantly, the content of heavy metals in both brewery sludge and soil are below the permissible limits of the United States Environmental Protection Agency (USEPA, 1997).

Table 5. Effect of brewery sludge on curd yields of cauliflower

\begin{tabular}{c|c|c|c|c}
\hline Parameters & Brewery sludge & USEPA (1997) limit & Soil & USEPA (1997) limit \\
\hline $\mathrm{pH}$ & 6.2 & - & 6.01 & - \\
$\mathrm{OM}(\mathrm{g} / \mathrm{kg})$ & 265.3 & - & 14.1 & - \\
$\mathrm{TN}(\mathrm{g} / \mathrm{kg})$ & 25.3 & - & 0.9 & - \\
$\mathrm{TP}(\mathrm{g} / \mathrm{kg})$ & 6.7 & - & 1.15 & - \\
$\mathrm{K}(\mathrm{g} / \mathrm{kg})$ & 7.3 & - & 0.34 & - \\
$\mathrm{Zn}(\mu \mathrm{g} / \mathrm{kg})$ & 558.47 & 3000 & 38.09 & 300 \\
$\mathrm{Cu}(\mu \mathrm{g} / \mathrm{kg})$ & 75.23 & 1500 & 10.66 & 100 \\
$\mathrm{~Pb}(\mu \mathrm{g} / \mathrm{kg})$ & 33.88 & 1000 & 11.91 & 350 \\
$\mathrm{Cr}(\mu \mathrm{g} / \mathrm{kg})$ & 34.98 & 1200 & 9.18 & 250 \\
$\mathrm{Cd}(\mu \mathrm{g} / \mathrm{kg})$ & 2.25 & 20 & 0.73 & 0.6 \\
\hline
\end{tabular}

\section{Effect of brewery sludge on curd yields of cauliflower}

The presence of heavy metals in BWWS affect the soil physicochemical characteristics. For example, soil zinc from $20 \mathrm{Mg}^{-1}$ BWWS application was significantly increased compared to 5 and $10 \mathrm{Mg} \mathrm{ha}^{-1}$ sludge addition. Higher rate application of BWWS was also increased the accumulation of copper and lead in soil significantly as compared to the other treatments The lowest copper and lead concentration was found in the control. This indicates that high loading rate of BWWS increases the accumulation of heavy metals in soil (see Fig. 8) (Khanal et al., 2014).

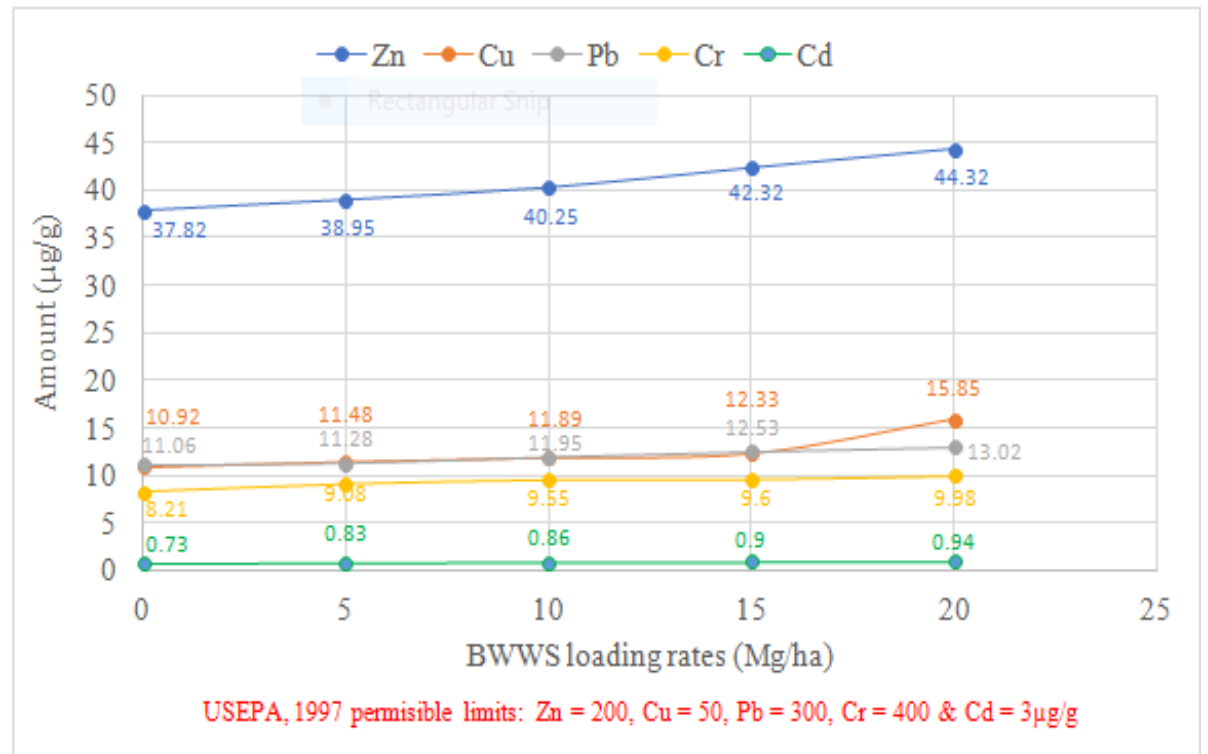

Figure 8. Effect of BWWS on heavy metals content of soil (control) 
A good percentage of nitrogen, phosphorus and potassium in sludge also make them a valuable resource for agricultural production. Such sludge is spread on land surface and when they decompose can serve as a source of those minerals to plant growth.

\section{The potential of BWSS as application of organic fertilizer}

\section{Grain protein content}

BWSS role on grain protein content was investigated in Ethiopia and the research result can be seen in Table 6. From this table, the wheat and teff protein contents were also differing among the various treatments. RIF treated crops gave the highest grain protein of $12.53 \%$ teff and $12.09 \%$ wheat owing to better grain nitrogen acceptance by wheat and teff. Control treated crops gave the lowest grain protein of $10.25 \%$ teff and 9.98\% wheat (Dessalew et al., 2017).

These results were in line with other researches by Lemon (2007), Blumenthal (2008) and also Mariani (1995). From all these researches, it can be seen that in addition to better performance in the biomass yields and grain of teff and wheat, BSDS also improves the grain protein content. In this regard, with BSDS as s substitute to RIF, it can greatly improve nutritional recompenses of low-contribution agroecosystems.

Table 6. Comparison of protein content of wheat and teff treated with BWSS (brewery spent sludge), FYM (farmyard manure) and RIF (recommended inorganic fertilizer) (Dessalew et al., 2017)

\begin{tabular}{|c|c|c|c|c|c|c|c|c|c|c|}
\hline \multirow{4}{*}{$\begin{array}{c}\text { Treatment } \\
\text { Protein content }\end{array}$} & \multicolumn{10}{|c|}{ Cereals } \\
\hline & \multicolumn{5}{|c|}{ Teff } & \multicolumn{5}{|c|}{ Wheat } \\
\hline & \multirow{2}{*}{\begin{tabular}{|c|} 
Control \\
-998
\end{tabular}} & \multirow{2}{*}{\begin{tabular}{|c|} 
FYM \\
-11.4
\end{tabular}} & \multirow{2}{*}{\begin{tabular}{|c|} 
BSD \\
-11.23
\end{tabular}} & \multicolumn{2}{|c|}{ RIF } & \multirow{2}{*}{\begin{tabular}{|c|} 
Control \\
10.25 \\
\end{tabular}} & \multirow{2}{*}{$\begin{array}{l}\text { FYM } \\
11.55 \\
\end{array}$} & \multirow{2}{*}{$\begin{array}{c}\text { BSD } \\
11.38 \\
\end{array}$} & \multicolumn{2}{|c|}{ RIF } \\
\hline & & & & 12.09 & - & & & & 12.53 & - \\
\hline $\begin{array}{l}\text { Comparison } \\
\text { group }\end{array}$ & $\begin{array}{l}\text { Control } \\
\text { vs FYM }\end{array}$ & $\begin{array}{c}\text { Control } \\
\text { vs BS }\end{array}$ & $\begin{array}{l}\text { Control } \\
\text { vs RIF }\end{array}$ & $\begin{array}{l}\text { BS vs } \\
\text { FYM }\end{array}$ & BS vs RIF & $\begin{array}{l}\text { Control vs } \\
\text { FM }\end{array}$ & $\begin{array}{c}\text { Control vs } \\
\text { BS }\end{array}$ & \begin{tabular}{|c|} 
Control vs \\
RIF
\end{tabular} & $\begin{array}{l}\text { BS vs } \\
\text { FYM }\end{array}$ & $\begin{array}{l}\text { BS vs } \\
\text { RIF }\end{array}$ \\
\hline Mean difference & -1.3 & -1.25 & -2.11 & -0.18 & -0.86 & -1.3 & -1.13 & -2.28 & 0.17 & -1.15 \\
\hline T-value & -25.2 & -48.4 & -71.7 & 13.7 & -33.3 & -33.9 & -26.2 & -66.8 & 3.7 & -27.4 \\
\hline P-value & 0.000 & 0.000 & 0.000 & 0.000 & 0.000 & 0.000 & 0.000 & 0.000 & 0.000 & 0.000 \\
\hline
\end{tabular}

A good percentage of nitrogen, phosphorus and potassium in sludge also make them a valuable resource for agricultural production. Such sludge is spread on land surface and when they decompose can serve as a source of those minerals to plant growth. The fertilizer value of sludge is evaluated by the percentage concentrations of nitrogen, phosphorus and potassium (NPK) present in it. A typical NPK value of recommended fertilizer has NPK composition of $8 \% \mathrm{~N}, 8 \% \mathrm{P}$ and $8 \% \mathrm{~K}$. It may become difficult to achieve these compositions of NPK value in sludge. From the results of NPK concentrations definitely do have fertilizer values. The aerobically digested brewery and textile sludge's indicates that a nutrient composition of $4.1 \% \mathrm{~N}, 2.0 \% \mathrm{P}, 0.6 \% \mathrm{~K}$ and $2.6 \% \mathrm{~N}, 0.5 \% \mathrm{P}$ and $0.6 \% \mathrm{~K}$. Whereas the results of anaerobically digested sludge indicate brewery sludge had $9.7 \% \mathrm{~N}, 0.9 \% \mathrm{P}$ and $1.4 \% \mathrm{~K}$. While textile processing sludge had a $\mathrm{N}, \mathrm{P}$, and $\mathrm{K}$ concentration of $9,0.2$ and $0.5 \%$ respectively. If these nutrients concentration are improved upon by a suitable complementary method such as composting, they can be used to fertilizer soil (Asia et al., 2008). The results of the fertilizer values (NPK) of the sludge are presented in Figure 9. 


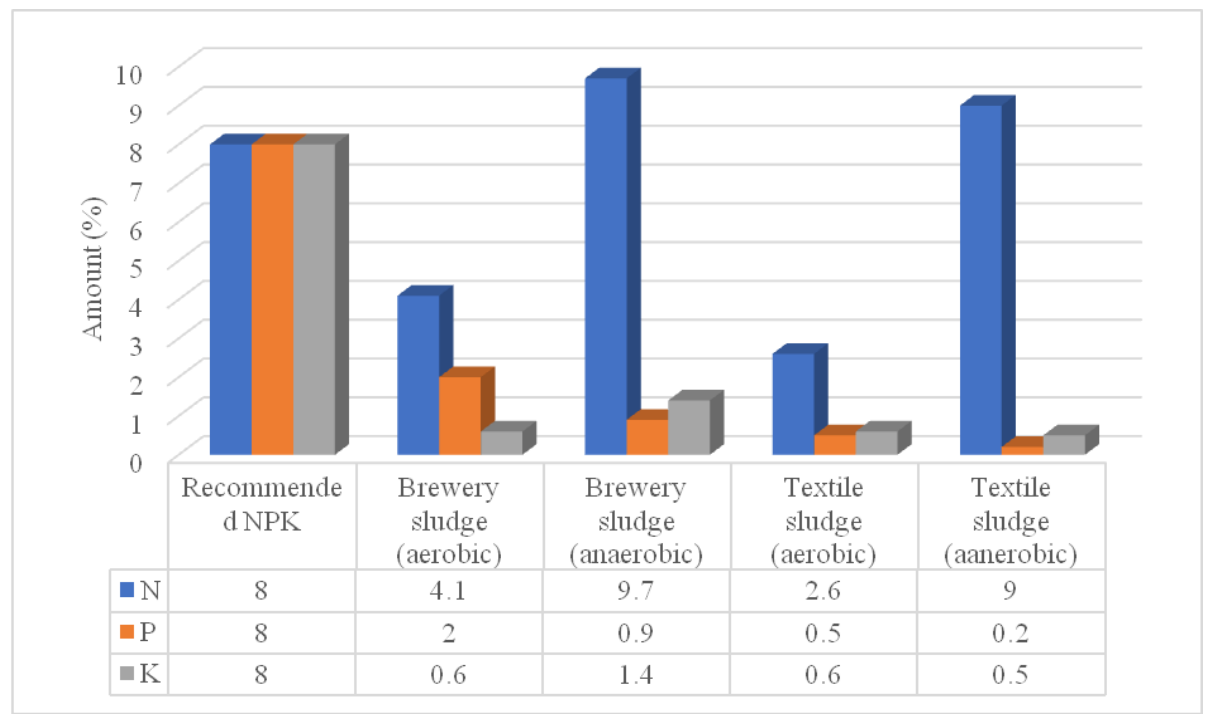

Figure 9. NPK value of anaerobically and aerobically processed brewery and textile sludge's

\section{Brewery waste sludge (BWWS) for vegetable and crop cultivation}

The pot experiment (500-g container germination study of chilly plant indicated that increased growth of the plants when compared to that controls (Fig. 10). However enhanced plant growth was observed with increasing proportions of brewery sludge in clay loamy soil. For example, plant height in 9:1, 8:2, and 7:3 amended with BWWS illustrates an increment in plant height (Ramya et al., 2015).

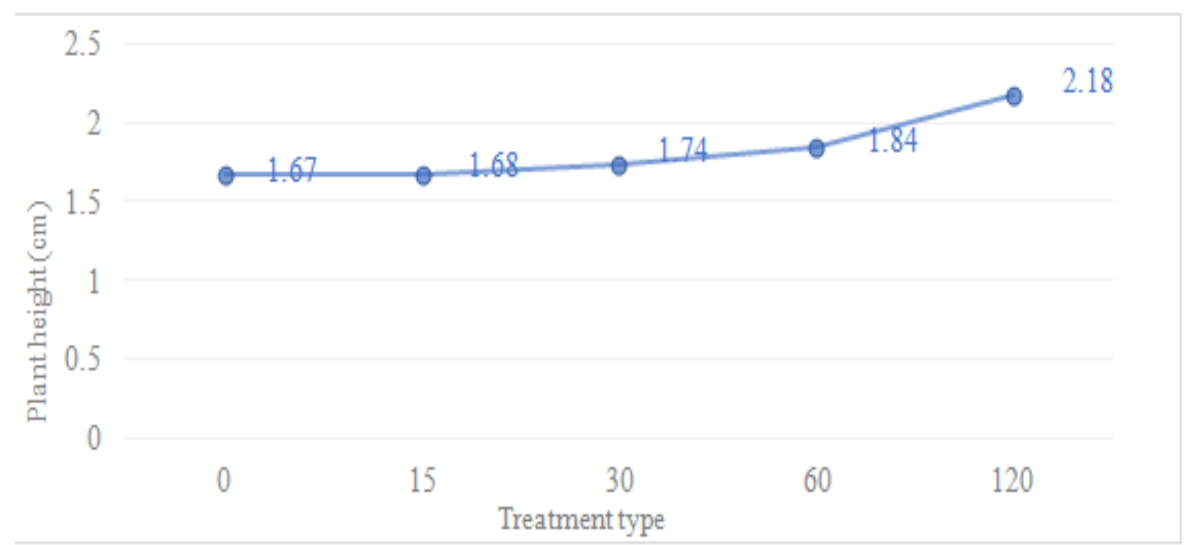

Figure 10. Comparison of plant height planted in clay loamy soil amended with brewery sludge

Beside this plant height increment, application of BWWS in river sand soil media has also shown a significant increase in yields. This confirms that brewery sludge would have a positive input for yield increase in relation to poor and semi-arid soils (Fig. 11).

\section{Improvement on grain yield}

Ramya et al. (2015) also agreed with Khan et al. (2014), in which the effect of brewery sludge (Fig. 12) on the yield of curd were shows an increasing trend with an increasing application of brewery sludge. The highest curd yield (i.e., $12.43 \mathrm{Mg} \mathrm{ha}^{-1}$ ) 
was obtained from $20 \mathrm{Mg} \mathrm{ha}^{-1}$ brewery sludge application rate whereas the lowest curd yield (i.e., 7.0 $\mathrm{Mg} \mathrm{ha}^{-1}$ ) was obtained from the soil (control). This highest yield was also significantly higher compared to the control and $5 \mathrm{Mg} \mathrm{ha}^{-1}$ brewery sludge application.

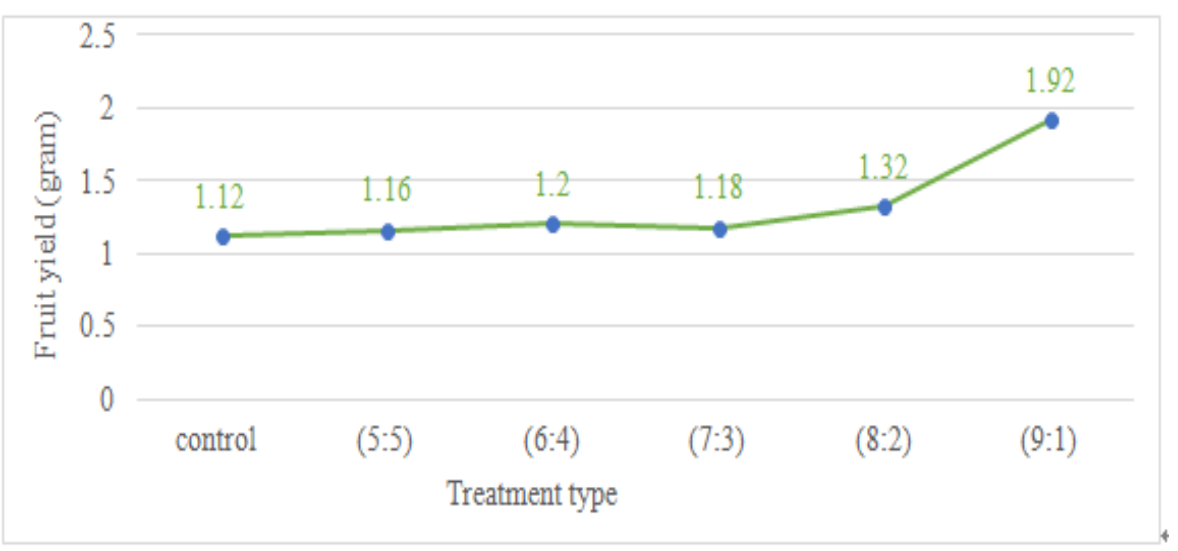

Figure 11. Comparison of fruit height cultivated in river sand amended with BWWS

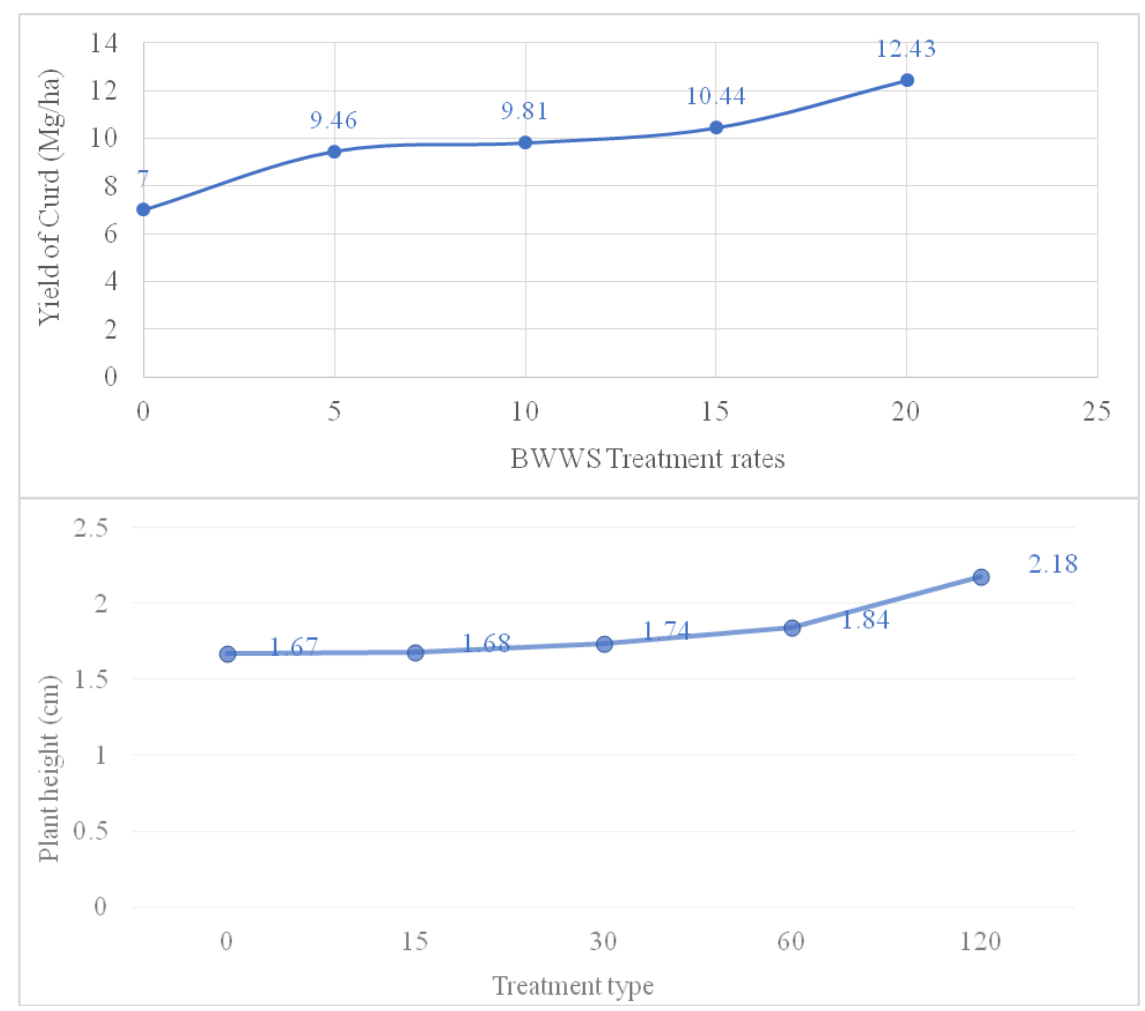

Figure 12. Role of BWWS on curd yields of cauliflower

However, Wendimagegn's (2016) research finding indicated that there was a negative effect on the yields of tomato fruit when brewery sludge loading rates was increased. According to Alemu et al.'s (2017) investigation, increased application from 0 to $15 \mathrm{t} \mathrm{ha}^{-1}$ to $2.5 \mathrm{t} \mathrm{ha}^{-1}$ increased plant height consistently. However, further increasing of sludge application from $2.5 \mathrm{t} \mathrm{ha}^{-1}$ to $15 \mathrm{t} \mathrm{ha}^{-1}$ not increased plant height 
significantly indicating the application of brewery sludge beyond $2.5 \mathrm{t} \mathrm{ha}^{-1}$ did not significantly increase plant height.

However, as compared to the control and NP fertilized plots, brewery sludge application at all levels showed significance difference and the increment ranged from 23 to $27 \%$ and 8 to $11 \%$ respectively. This increment in plant height is due to the increase in crop cell elongation and cell division improved as a result of application of brewery sludge that might enhanced availability of essential nutrients for the growth of plants. Similarly, total grain yield of sorghum crop was affected significantly by application of brewery sludge, where sludge at $15 \mathrm{t} \mathrm{ha}^{-1}$ treated plot gave the highest (4081.6 kg/ha) mean grain yield. When averaged across the application levels, sorghum grain yield showed a significant variation due to the brewery sludge application. The sludge treated plots produced 261.7 and $75.6 \%$ more grain yield than that of control and NP applied plots, respectively. The low response to NP might have been due to the fact that part of the applied NP would not be available to plants, rather it tends to fixed by the soil and existing available nutrients reserve of the soil might be very low (Fig. 13).

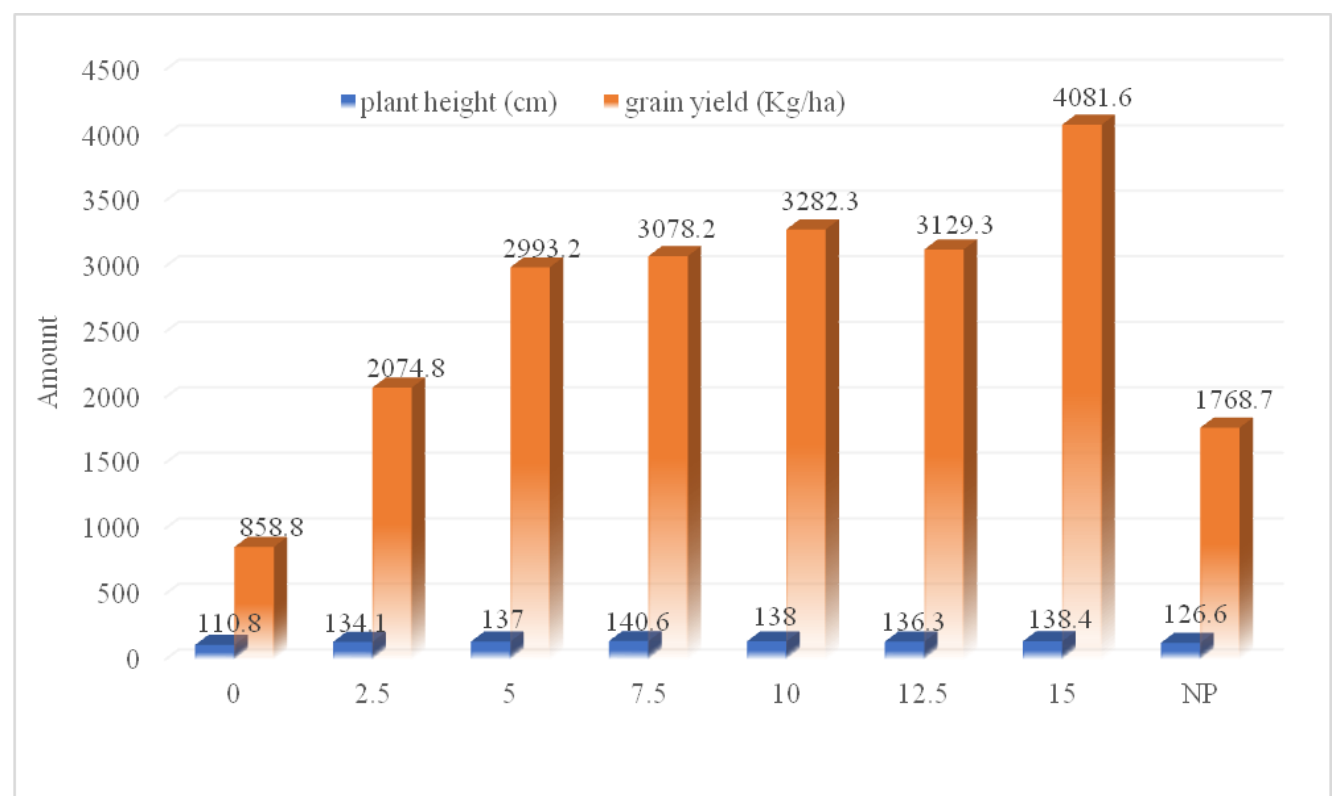

Figure 13. Plant height and grain yield of sorghum cultivated under different levels of BWWS and NP

In addition to this, the results of a research conducted in one of the city found in Ethiopia on Teff and wheat grain yield can be seen in Figure 14 and Table 7. From these results, RIF gave the highest yields followed by soils that were added BWSS and lastly the soils where no was fertilizer added (control) and those for FYM. From the addition of BWSS for both teff and wheat, the yields were doubled in comparison with the yields from control; 1.5 times for teff and 1.3 for wheat in comparison with the yields from FYM. This gave a yield of $2.45 \mathrm{t} / \mathrm{ha}$ for teff and $2.65 \mathrm{t} / \mathrm{ha}$ for wheat in Ethiopia (Dessalew et al., 2017). This increase in yields goes hand in hand with other research works such as Luque et al. (1990) and Iliescu (2009). Therefore, BWSS can serve as a good organic fertilizer that can be applied in the farming areas which is cost effective and with lesser enduring undesirable significances for the quality of water and soil, along with the general public health. 


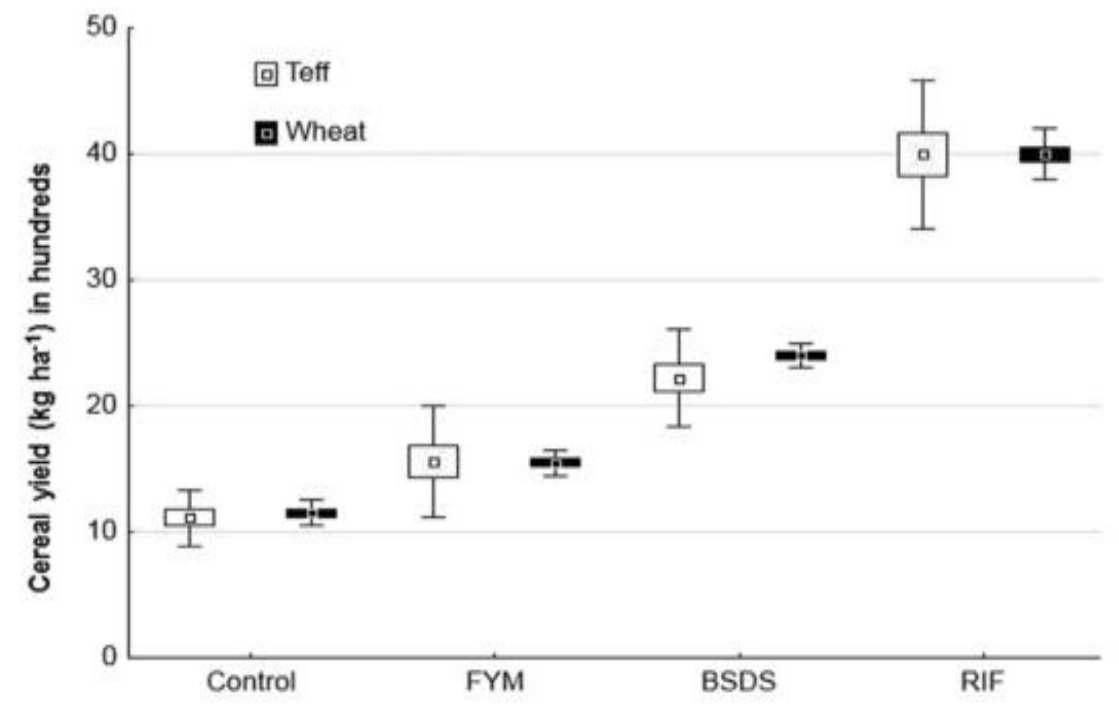

Figure 14. Box plot showing cereals yield among the different treatment groups (control, FYM $1 / 4$ farmyard manure, BWSS 1/4 brewery spent sludge; RIF 1/4 recommended inorganic fertilizer).

Boxes represent the mean \pm standard error and whiskers represent two standard deviations

Table 7. comparison of grain and biomass yields for wheat and teff treated with BWSS (brewery waste sludge), FYM (farmyard manure) and RIF (recommended inorganic fertilizer)

\begin{tabular}{|c|c|c|c|c|c|c|c|c|c|c|}
\hline \multirow{3}{*}{ Treatment } & \multicolumn{10}{|c|}{ Cereals } \\
\hline & \multicolumn{5}{|c|}{ Teff } & \multicolumn{5}{|c|}{ Wheat } \\
\hline & Control & FYM & BWS & \multicolumn{2}{|c|}{ RIF } & Control & FYM & BWS & \multicolumn{2}{|c|}{ RIF } \\
\hline Grain yield $\left(\mathrm{kg} \mathrm{ha}^{-1}\right)$ & -1111.1 & 1555.6 & 2222.2 & \multicolumn{2}{|c|}{$4000-$} & -1150.0 & -155 & 2400 & \multicolumn{2}{|c|}{12496} \\
\hline Comparison group & \begin{tabular}{c|} 
Control \\
vs FYM
\end{tabular} & $\begin{array}{l}\text { Control } \\
\text { vs BWS }\end{array}$ & $\begin{array}{l}\text { Control } \\
\text { vs RIF }\end{array}$ & $\begin{array}{c}\text { BWS vs } \\
\text { FYM }\end{array}$ & $\begin{array}{c}\text { BWS vs } \\
\text { RIF }\end{array}$ & $\begin{array}{c}\text { Control } \\
\text { vs FM }\end{array}$ & \begin{tabular}{|c|}
$\begin{array}{c}\text { Control vs } \\
\text { BWS }\end{array}$ \\
\end{tabular} & $\begin{array}{l}\text { Control } \\
\text { vs RIF }\end{array}$ & $\begin{array}{l}\text { BS vs } \\
\text { FYM }\end{array}$ & $\begin{array}{c}\text { BWS vs } \\
\text { RIF }\end{array}$ \\
\hline Mean difference & -0.0440 & 0.1111 & -0.2889 & 0.066 & 0.1780 & -0.158 & -0.640 & -0.640 & 0.112 & -0.370 \\
\hline T-value & -3.11 & -8.66 & -15.92 & 3.928 & -8.76 & -6.72 & -11.64 & -26.9 & 6.95 & -22.54 \\
\hline P-value & 0.036 & 0.001 & 0.000 & 0.017 & 0.009 & 0.003 & 0.000 & 0.000 & 0.002 & 0.000 \\
\hline \multicolumn{11}{|c|}{ Biomass yield $\left(\mathrm{kg} \mathrm{ha}^{-1}\right)$} \\
\hline \multirow{3}{*}{ Treatment } & \multicolumn{10}{|c|}{ Cereals } \\
\hline & \multicolumn{5}{|c|}{ Teff } & \multicolumn{5}{|c|}{ Wheat } \\
\hline & Control & FYM & BWS & \multicolumn{2}{|c|}{ RIF } & Control & FYM & BWS & \multicolumn{2}{|c|}{ RIF } \\
\hline Grain yield $\left(\mathrm{kg} \mathrm{ha}^{-1}\right)$ & 2785 & 4852 & 6568 & 12460 & - & 2938 & 4876 & 7164 & 12496 & \\
\hline Comparison group & $\begin{array}{c}\text { Control } \\
\text { vs FYM }\end{array}$ & \begin{tabular}{l|c} 
Control \\
vs BWS
\end{tabular} & $\begin{array}{c}\text { Control } \\
\text { vs RIF }\end{array}$ & $\begin{array}{c}\text { BWS vs } \\
\text { FYM }\end{array}$ & $\begin{array}{c}\text { BWS vs } \\
\text { RIF }\end{array}$ & $\begin{array}{c}\text { Control } \\
\text { vs FM }\end{array}$ & \begin{tabular}{|c|}
$\begin{array}{c}\text { Control vs } \\
\text { BS }\end{array}$ \\
\end{tabular} & $\begin{array}{l}\text { Control } \\
\text { vs RIF }\end{array}$ & $\begin{array}{c}\text { BWS vs } \\
\text { FYM }\end{array}$ & $\begin{array}{c}\text { BWS vs } \\
\text { RIF }\end{array}$ \\
\hline Mean difference & -2067 & -3783 & -9675 & -1716 & -5892 & -1938 & -4226 & -9558 & -2288 & -5332 \\
\hline T-value & -2414 & -547.9 & -544.6 & -204.6 & -333.2 & -281.7 & -793.9 & -1850.9 & -348.9 & -1128.3 \\
\hline P-value & 0.000 & 0.000 & 0.000 & 0.000 & 0.000 & 0.000 & 0.000 & 0.000 & 0.000 & 0.000 \\
\hline
\end{tabular}

(Source; G. Dessalew et al. 2017)

\section{Biomass yield}

As the result showed in Table 7, the treatments between biomass harvest showed substantial variances $(\mathrm{p}<0.05)$ during the analysis of variance. BWSS usage gave far much better results than FYM (farmyard manure) but lower than RIF (recommended inorganic fertilizer). Like in the case of the grains, the addition of (Brewery waste 
sludge) BWSS for biomass yields, were doubled in comparison with the yields from control; 1.5 times for teff and 1.3 for wheat in comparison with the yields from FYM; but lesser yields when compared to RIF due to the fast release of if RIF than BWSS (Dessalew et al., 2017).

\section{Conclusions and recommendations}

\section{Conclusions}

Brewery wastewater sludge is generated as the result of biological wastewater treatment process. Previously, this sludge is considered as a waste product, but now it can be substituted for fertilizers and avoid the need of costly inputs of chemical fertilizers because of its valuable nutrients for plant growth and high water retention capacity. To do this, cost effective and environmentally friendly treatment technique should be developed to convert brewery sludge into bio-fertilizer. Composting with other organic wastes like straw and paper generally offers a relatively cheap and environmentally sound method of recycling organic brewery by-products.

Currently, in Ethiopia there is an increased expansion of agro-industrial sectors mainly beverage industries. This expansion may increase sludge production along with increase in their beer productions. Therefore, it is inevitable to focus on the development of appropriate agro-industrial sludge waste management strategy enabling to reutilize the sludge in an environmentally friendly manner.

\section{Recommendations}

Most of the Ethiopian breweries have wastewater treatment plant and generates large amount of sludge which is disposed anywhere. Limited research evidences are available (i.e., only restricted to Harare sofi and Heineken breweries) on the possibility of recycling brewery wastewater sludge for land application at pilot scale levels. Therefore, more research has to be investigated on potential fertilizer values of Ethiopian breweries wastewater sludge's.

\section{REFERENCES}

[1] Abushammala, M. F., Basri, N. E. A., Kadhum, A. A. H. (2009): Review on landfill gas emission to the atmosphere. - European Journal of Scientific Research 30: 427-436.

[2] Alemu, D. N., Ahmed, A., Mohammed, M. (2017): Impact of Brewery waste sludge on sorghum (Sorghum bicolor L. Moench) productivity and soil fertility in Harari Regional State, Eastern Ethiopia. - Turkish Journal of Agriculture, Food Science and Technology 5: 366-372.

[3] Arthurson, V. (2008): Proper sanitization of sewage sludge: a critical issue for a sustainable society. - Appl. Environ. Microbiol. 74: 5267-5275.

[4] Asia, I. O., Ekpo, K., Chukwuedo, M. (2008): Economic importance and application options of some industrial sludge conditioned by different treatment methods. - African Journal of Biotechnology 7(14).

[5] Babel, S., Sae-Tang, J., Pecharaply, A. (2009): Anaerobic co-digestion of sewage and brewery sludge for biogas production and land application. - International Journal of Environmental Science \& Technology 6: 131-140.

[6] Berni, M., Dorileo, I., Nathia, G., Forster-Carneiro, T., Lachos, D., Santos, B. G. (2014): Anaerobic digestion and biogas production: combine effluent treatment with energy 
generation in UASB reactor as biorefinery annex. - International Journal of Chemical Engineering. http://dx.doi.org/10.1155/2014/543529.

[7] Blumenthal, J., Baltensperger, D., Cassman, K., Mason, S., Pavlista, A. (2008): Importance and Effect of Nitrogen on Crop Quality and Health. - Agronomy \& Horticulture - Faculty Publications. http://digitalcommons.unl.edu/agronomyfacpub/, 200.

[8] Bodík, E. G., Kapusta, Š., Derco, I. J. (2005): Evaluation of anaerobic-aerobic wastewater treatment plant operations. - Polish Journal of Environmental Studies 14: 29-34.

[9] Dessalew, G., Beyene, A., Nebiyu, A., Ruelle, M. L. (2017): Use of industrial diatomite wastes from beer production to improve soil fertility and cereal yields. - Journal of cleaner production 157: 22-29.

[10] Dolgen, D., Alpaslan, M. N., Delen, N. (2004): Use of an agro-industry treatment plant sludge on iceberg lettuce growth. - Ecological Engineering 23: 117-125.

[11] Dos Santos Mathias, T. R., De Mello, P. P. M., Ervulo, E. F. C. (2014): Solid wastes in brewing process: A review. - Journal of Brewing and Distilling 5: 1-9.

[12] Ediget, W. (2016): The Fertilizing Potential of Breweries Waste Water Sludge Compared to Urea on the Growth and Yield of Tomato Plant. - Center for Environmental Science Program. Addis Ababa University College Of Natural Sciences.

[13] Erdem, N., Ok, S. S. (2002): Effect of brewery sludge amendments on some chemical properties of acid soil in pot experiments. - Bioresource Technology 84: 271-273.

[14] Evans, T. D. (2008): An Independent Review of Sludge Treatment Processes and Innovations. - Australian Water Association Bio-Solids Conference, Adelaide.

[15] Fillaudeau, L., Blanpain-Avet, P., Daufin, G. (2006): Water, wastewater and waste management in brewing industries. - Journal of Cleaner Production 14: 463-471.

[16] Garg, N. K., Tanyimboh, T. (2009): Multi-criteria assessment of alternative sludge disposal methods. - Unpublished M. Sc. Thesis. Department of Mechanical Engineering, University of Strathclyde.

[17] Hänel, K. (1988): Biological Treatment of Sewage by the Activated Sludge Process. - E. Horwood, Chichester.

[18] Iliescu, M., Faraco, M., Popa, M., Cristea, M. (2009): Reuse of residual kieselguhr from beer filtration. - J. Environ. Prot. Ecol. 10: 156-162.

[19] Kanagachandran, K., Jayaratne, R. (2006): Utilization potential of brewery waste water sludge as an organic fertilizer. - Journal of the Institute of Brewing 112: 92-96.

[20] Khanal, B. R., Shah, S. C., Sah, S. K., Shriwastav, C. P., Acharya, B. S. (2014): Heavy metals accumulation in cauliflower (Brassica oleracea L. var. botrytis) grown in brewery sludge amended sandy loam soil. - Int. J. Agric. Technol 2: 87-92.

[21] Lemon, J. (2007): Nitrogen Management for Wheat Protein and Yield in the Esperance Port Zone. - Department of Agriculture and Food, State of Western Australia.

[22] Luque, O., Bracho, O., Maier, T. (1990): Utilization of Brewery Waste Water Sludge for Soil Improvment. - Technical Quarterly, Master Brewers Association of the Americas, USA.

[23] Mariani, B. M., D'egido, M. G., Novaro, P. (1995): Durum wheat quality evaluation: influence of genotype and environment. - Cereal Chem. 72(2): 194-197.

[24] Mesfin, A. (2007): Nature and Management of Acidic Soil in Ethiopia. - Addis Abeba, Ethiopia.

[25] Olowu, R., Osundiya, M., Onwordi, C., Denloye, A., Okoro, C., Tovide, O., Majolagbe, A., Omoyeni, O., Moronkola, B. (2012): Pollution status of brewery sewage sludge in Lagos, Nigeria. - International Journal of Research and Reviews in Applied Sciences 10: 159-165.

[26] Ramya, N., Srinivas, T., Lakshmi, K. A. (2015): Studies on effect of brewery waste water sludge (BWS) on morphology and yield of chilly (Capsicum annum 1.) plant. International Journal of Pharmaceutical Sciences and Research 6: 405. 
[27] Sampson, E. I. (2016): Fertilizer value of bio-solids produced from the treatment of wastewater sludge. - TLEP International Journal of Chemical Engineering Research 2: 14-24.

[28] Şengün, T. (2007): Use of agro industry treatment plant sludge for agricultural purposes. - Dokuzeylul University. Master's thesis, environmental engineering.

[29] Stocks, C., Barker, A., Guy, S. (2002): The composting of brewery sludge. - Journal of the Institute of Brewing 108: 452-458.

[30] Stout, J. K. (2002): Sludge Management in Alfenas, Brazil. - Massachusetts Institute of Technology, Cambridge, MA.

[31] Sullivan, D. M. (2015): Fertilizing with Biosolids. - Oregon State University, PNW 508.

[32] Tadese, A., Seyoum, L. A. (2015): Evaluation of selected wetland plants for removal of chromium from tannery wastewater in constructed wetlands, Ethiopia. - African Journal of Environmental Science and Technology 9: 420-427.

[33] Thomas, K., Rahman, P. (2006): Brewery wastes. Strategies for sustainability. A review. - Aspects of Applied Biology 80: 147-153.

[34] USEPA (1997). Exposure Factors Handbook. - EPA, Washington, DC.

[35] Usman, K., Khan, S., Ghulam, S., Khan, M. U., Khan, N., Khan, M. A., Khalil, S. K. (2012): Sewage sludge: an important biological resource for sustainable agriculture and its environmental implications. - American Journal of Plant Sciences 3: 1708.

[36] Wendimagegn, E. (2016): The fertilizing potential of breweries waste water sludge compared to urea on the growth and yield of tomato plant. - Msc Thesis, Addis Ababa University College of Natural Sciences.

[37] www.waterleav.com (2017): Integrated Sludge Treatment, Protecting the 4 Elements. Herent (Leven), Belgium. 